Illinois State University

ISU ReD: Research and eData

Theses and Dissertations

3-21-2017

\title{
Exploration Of The Northern Illinois Bedrock Surface
}

Matthew Rhoads

Illinois State University, mrhoads1@gmail.com

Follow this and additional works at: https://ir.library.illinoisstate.edu/etd

Part of the Geology Commons

\section{Recommended Citation}

Rhoads, Matthew, "Exploration Of The Northern Illinois Bedrock Surface" (2017). Theses and Dissertations. 704.

https://ir.library.illinoisstate.edu/etd/704

This Thesis is brought to you for free and open access by ISU ReD: Research and eData. It has been accepted for inclusion in Theses and Dissertations by an authorized administrator of ISU ReD: Research and eData. For more information, please contact ISUReD@ilstu.edu. 


\title{
EXPLORATION OF THE NORTHERN ILLINOIS BEDROCK SURFACE
}

\author{
Matthew L. Rhoads
}

42 Pages

The purpose of this study is to deconstruct the relationship between the Leaf River anticline and the preglacial bedrock paleo topography at the eastern terminus of the Plum River Fault Zone in Ogle County, Illinois. A geostatistical approach was used to model the subsurface elevation of the bedrock paleo topography and the Leaf River anticline. The contour maps derived from the elevation models provided detailed depictions of the ancient bedrock landscape and subsurface structure in the study area. The Leaf River anticline is interpreted to be a component of hanging wall anticline at the terminus of the Plum River Fault Zone. The topographic high created by the anticline controlled local drainage and led to the development of the Leaf River paleovalley prior to the Pleistocene. The catastrophic failure of an ice damn during the Illinois Glacial Episode carved a glacial spillway into the north flank of the Leaf River anticline that interfaced with a tributary of the Leaf River paleovalley. This rerouted the preglacial drainage network and permanently diverted the ancient Rock River to its modern day position. Ultimately, the subsurface geometry of the Leaf River anticline and its relationship to the local bedrock paleo topography was revealed by the elevation models. The position and development of the Leaf River paleovalley and glacial spillway interpreted in this study aligned with the regional interpretations for the evolution of the ancient bedrock landscape established in prior works. However, this study revealed that the Leaf River anticline, and by association, the 
terminus of the Plum River Fault Zone extends farther east into the region than indicated by prior works.

KEYWORDS: Paleogeography, Fault zones, Structure contour mapping, Geostatistics 
MATTHEW L. RHOADS

A Thesis Submitted in Partial Fulfillment of the Requirements for the Degree of

MASTER OF SCIENCE

Department of Geography-Geology

ILLINOIS STATE UNIVERSITY

2017 
Copyright 2017 Matthew L. Rhoads 
EXPLORATION OF THE NORTHERN ILLINOIS BEDROCK SURFACE

MATTHEW L. RHOADS

COMMITTEE MEMBERS:

David H. Malone, Chair

Robert S. Nelson

Lisa M. Tranel 


\section{ACKNOWLEDGMENTS}

Thank you to my glorious wife. She is the one who encouraged me to give graduate school a shot in the first place. I would not have gotten this far without her.

M.L.R. 


\section{CONTENTS}

Page

ACKNOWLEDGMENTS

$\begin{array}{ll}\text { CONTENTS } & \text { ii }\end{array}$

TABLES

FIGURES

CHAPTER I: INTRODUCTION 1

Northern Illinois Bedrock Geology 1

$\begin{array}{ll}\text { Stratigraphy } & 2\end{array}$

$\begin{array}{ll}\text { St. Peter Sandstone } & 2\end{array}$

Platteville Group $\quad 3$

Galena Group $\quad 3$

Additional Formations $\quad 3$

$\begin{array}{ll}\text { Structure } & 6\end{array}$

$\begin{array}{ll}\text { Plum River Fault Zone } & 6\end{array}$

Leaf River Anticline $\quad 6$

$\begin{array}{ll}\text { Preglacial Paleogeography } & 10\end{array}$

$\begin{array}{ll}\text { Leaf River Paleovalley } & 10\end{array}$

$\begin{array}{ll}\text { Glacial Spillway } & 10\end{array}$

$\begin{array}{ll}\text { Purpose } & 12\end{array}$

$\begin{array}{ll}\text { Research Questions } & 12\end{array}$

$\begin{array}{ll}\text { Study Area } & 13\end{array}$

CHAPTER II: METHODS 16 
Geologic Database

Data Selection

Data Input

Data Processing

Geostatistics

Regionalized Variable

Semivariance

Modeled Variogram

Ordinary Kriging

Uncertainty Analysis

Root Mean Square Error

Coefficient of Determination

F-Test

Computer Based Modeling

CHAPTER III: RESULTS

Geologic Database

Observed Wells

Synthetic Wells

Model Domain

Domain Construction

Geologic Control

Uncertainty Analysis

Root Mean Square Error 
$\begin{array}{lr}\text { Plotting Elevation Models } & 29\end{array}$

$\begin{array}{lr}\text { St. Peter Top Contour Map } & 29\end{array}$

Bedrock Surface Contour Map 31

$\begin{array}{ll}\text { CHAPTER IV: DISCUSSION } & 33\end{array}$

Leaf River Anticline 33

$\begin{array}{ll}\text { Plum River Fault Zone } & 33\end{array}$

$\begin{array}{ll}\text { Rock River Diversion } & 36\end{array}$

$\begin{array}{ll}\text { CHAPTER V: CONCLUSION } & 37\end{array}$

$\begin{array}{ll}\text { REFERENCES } & 39\end{array}$ 


\section{TABLES}

Table

Page

Table 1. Summary statistics for wells in the geodatabase.

Table 2. Uncertainty analysis results for estimated elevations. 


\section{FIGURES}

Figure

Figure 1. Stratigraphic column for Northern Illinois. 5

$\begin{array}{ll}\text { Figure 2. Bedrock structure in northern Illinois. } & 7\end{array}$

Figure 3. Structure contour and cross section of the Glenwood Formation. 8

Figure 4. Top of the Cambrian Franconia Formation. 9

Figure 5. Paleogeographic map for the Galena Upland in Northern Illinois. 11

Figure 6. The geographic location of the study area. 14

Figure 7. Aerial imagery showing bedrock exposed in quarries along the Rock River 15

Figure 8. Model domain and wells used for elevation modeling. 26

Figure 9. Residual plots for the Bedrock surface and St. Peter top. 28

Figure 10. Elevation contour map of the St. Peter Top. 30

Figure 11. St. Peter top contour map placed on top of regional structure. 30

Figure 12. The elevation contour map for the buried bedrock paleo topography. 32

Figure 13. Bedrock contour map placed on top of the regional paleo topography. 32

Figure 14. Precambrian basement terranes in the north-central United States. 35 


\section{CHAPTER I: INTRODUCTION}

\section{Northern Illinois Bedrock Geology}

The ancient bedrock landscape of northern Illinois is obscured by a mantle of glacial drift deposited during Pleistocene Epoch (Leverett, 1921; Leighton and Brophy, 1961). Driven by glacial-fluvial activity, ancient paleovalleys developed on the bedrock surface before and during glaciation (Horberg and Anderson, 1956). Sediment-laden meltwater deposited thick successions of outwash sediments within paleovalleys (Kempton et al., 1991; Lau et al, 2016). Outburst floods from ice damned glacial lakes formed spillway channels and diverted the flow of rivers into adjacent paleovalleys (Kehew and Clayton, 1986). Massive sheets of glacial ice created bedrock depressions that overloaded and reversed preglacial drainage networks (McGinnis, 1968; Willman and Frye, 1970, Anderson, 1988).

Beneath the mantle of glacial drift, the geomorphic and structural history of the region is etched into the Ordovician carbonate and siliciclastic units that comprise the bedrock geology. Paleozoic faults and folds generated by the reactivation of Precambrian suture zones cut across the region (Kolata, 1976; Ludvigson and Bunker, 1989; Marshak et al., 2003; Craddock et al., 2017). A complex network of paleovalleys and tributaries, first developed as early as the Mesozoic, are superimposed on the bedrock units (Leverett, 1895; Horberg, 1950; Frye 1963). Because of the glacial modification, these paleovalleys now exist largely in the subsurface, only breaching the land surface at a few isolated outcrops.

The paleo topography of the ancient bedrock geology in northern Illinois was examined throughout the first half of the $20^{\text {th }}$ century during the search for water and aggregate resources in the region (Leverett, 1895; Workman, 1937; Horberg, 1950; Frye 1963; McGinnis, 1968). Following these early works, the Ordovician lithostratigraphic units were studied in detail during 
the 1970's and 1980's (Willman, 1973; Willman and Kolata, 1978; Kolata and Graese, 1983; Vishocky et al., 1985). Additionally, limited geophysics and structural mapping was conducted in the 1970's and 1980's to determine the approximate boundaries and orientation of prominent Sandwich and Plum River Fault zones that cut across the region (Kolata and Buschbach, 1976; Kolata and Bushbach, 1978, Ludvigson and Bunker, 1989). More recently, several 1:24,000 scale geologic maps were published in Ogle County. These maps focus on the Sandwich Fault

Zone (Kolata, 2012; Seid, 2010, 2010, 2011) and Pleistocene glacial units (Kron, 2011; Morgan, 2013).

\section{Stratigraphy}

\section{St. Peter Sandstone}

The St. Peter Sandstone is the basal formation of the Ancell Group (figure 1) deposited during the Tippecanoe transgression in the middle Ordovician Period (Willman, 1973; Willman and Kolata, 1978). The Tippecanoe sequence marked the beginning of a major transgressive cycle across Laurentia. Regionally, the rise in sea level controlled the deposition of a northeast to southwest swath of blanket quartz-rich sand (Willman and Kolata 1978; Kolata and Buschbach, 1983). Locally, the St. Peter is a 240-450 feet (73-137 meters) thick, light grey to yellow, crossbedded super mature quartz arenite (Seid, 2010; 2010; 2011). The St. Peter is prolific aquifer that supplies much of northern Illinois with potable water (Abrams et al., 2015). Due to the purity of the quartz sand, the formation is also a valuable industrial mineral that is actively mined in the region (Visocky et al., 1985). 


\section{Platteville Group}

The Platteville Group conformably overlies the St. Peter Formation (figure 1). As sea level continued to rise during the Tippecanoe transgression, the barrier island complexes were inundated with warm tropical waters (Willman, 1973; Willman and Kolata, 1978). The change in depositional environment fueled the deposition of fossiliferous carbonates rocks belonging to the Platteville Group. The Galena Group is 85-135 feet (26-41 meters) thick argillaceous, cherty, and fossiliferous dolomite (Seid, 2010; 2010; 2011; Kolata, 2012). Dolomites belonging to this group are highly bioturbated and known for diverse fauna. Common fossils include brachiopods, mollusks, bryozoans (Willman and Kolata, 1973).

\section{Galena Group}

Conformably overlaying the Platteville Group, the Galena Group was produced by the same shallow marine environment created by the Tippecanoe transgression (figure 1) (Willman, 1973; Willman and Kolata, 1978). The tropical sea that covered northern Illinois deepened and continued to deposit a uniform blanket fossiliferous carbonate rocks. The Galena Group contains larger portions of clay and interbedded shales, differentiating it from the Platteville Group (Willman and Kolata 1978; Kolata and Graese, 1983). Locally, the Galena Group is 50 to 250 feet (15-76 meters) thick and is highly dolomitized with interbedded shale and chert lenses (Seid, 2010; 2010; 2011; Kolata, 2012). In Northern Illinois, Galena Group carbonates are extensively quarried for industrial aggregates (Willman and Kolata, 1973).

\section{Additional Formations}

The bedrock surface in the region is dominantly comprised of the Galena, Platteville, and St. Peter formations (figure 1). These three units will be the focus of this investigation. However, two additional formations in the will be used to support the discussion. The Glenwood formation 
is an Ordovician aged interbedded sandstone and shale that is between 0-75 feet (0-23 meters) thick (figure 1). Traditionally, the Glenwood was used as a marker horizon for the facies transition between the St. Peter sandstone and Platteville carbonates. However, the Glenwood is a discontinuous unit that is not present everywhere in northern Illinois (Willman, 1973; Willman and Kolata, 1978). The Franconia formation is a Cambrian aged interbedded shale, siltstone, and sandstone that is between 50-150 feet (15-46 meters) thick (figure 1). The Franconia formation was a used as marker horizon for the correlation of strata belonging to the Sauk Sequence and the identification of the regional structure (Kolata and Graese, 1983). 


\begin{tabular}{|c|c|c|c|c|c|c|c|}
\hline $\begin{array}{l}\text { AGE } \\
M\end{array}$ & SYSTEM & SERIES & GROUP & FORMATION & LITHOLOGY & DESCRIPTION & \begin{tabular}{|c|} 
THICKNESS \\
$\mathrm{n}(\mathrm{m})$ \\
\end{tabular} \\
\hline$\frac{\infty}{\dot{0}}$ & 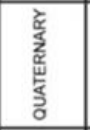 & 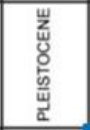 & - & - & o & LOESS, TLL, OUTWASH & $\begin{array}{l}0-250 \\
(0-75)\end{array}$ \\
\hline \multirow{9}{*}{$\frac{8}{9}$} & \multirow{9}{*}{$\begin{array}{l}z \\
\frac{3}{0} \\
\frac{0}{0} \\
\frac{8}{0}\end{array}$} & \multirow{6}{*}{ 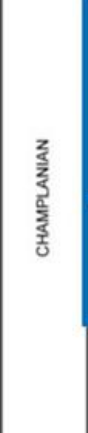 } & \multirow{3}{*}{ Galena } & WISE LAKE & $\frac{2,7}{1,1,2} \cdots$ & DOLOMITE & $\begin{array}{l}110 \\
(35)\end{array}$ \\
\hline & & & & DUNLETTH & 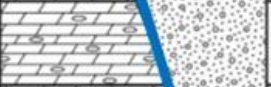 & DOLOMITE, CHERTY & $\begin{array}{l}130 \\
(40)\end{array}$ \\
\hline & & & & GUTTENBERG & $\frac{12}{17}$ & DOLOMITE, SHALE & $\begin{array}{l}20 \\
(6)\end{array}$ \\
\hline & & & PLATTEVILLE & - & 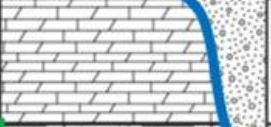 & LMESTONE, DOLOMITE & $\begin{array}{l}85-130 \\
(26-40)\end{array}$ \\
\hline & & & & GLENWOOO & $\square$ & SANOSTONE, SILTY & $5(1.5)$ \\
\hline & & & ANCELL & ST. PETER & & SANDSTONE & $\begin{array}{l}70-160 \\
(20-50)\end{array}$ \\
\hline & & \multirow{3}{*}{ 产 } & \multirow{3}{*}{$\begin{array}{l}\text { PRAIRIE DU } \\
\text { CHIEN }\end{array}$} & SHAKOPEE & 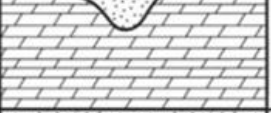 & DOLOMITE & $\begin{array}{l}205 \\
(60)\end{array}$ \\
\hline & & & & NEW RICHMOND & $4 \quad$ & SANDSTONE & $\begin{array}{l}50 \\
(15) \\
\end{array}$ \\
\hline & & & & ONEATA & 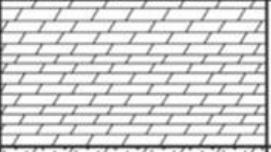 & DOLOMITE & $\begin{array}{l}100 \\
(33)\end{array}$ \\
\hline \multirow{6}{*}{ 高 } & \multirow{6}{*}{ 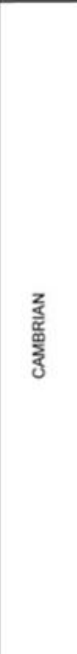 } & \multirow{6}{*}{ 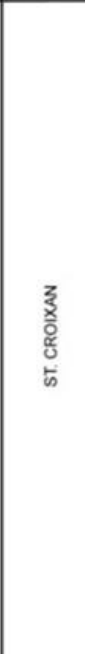 } & \multirow{6}{*}{-} & EMINENCE & $6,2,2,2,2$ & DOLOMITE, SANDY & $\begin{array}{l}60 \\
(20) \\
\end{array}$ \\
\hline & & & & POTOSI & 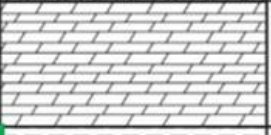 & DOLOMITE & $\begin{array}{l}165 \\
(50)\end{array}$ \\
\hline & & & & FRANCONIA & & $\begin{array}{l}\text { SANDSTONEE, } \\
\text { SILISTONE, SHALE }\end{array}$ & $\begin{array}{l}{ }_{(40}^{130} \\
(40)\end{array}$ \\
\hline & & & & $\begin{array}{l}\text { IRONTON. } \\
\text { GALESVILLE }\end{array}$ & & SANDSTONE & $\begin{array}{l}{ }_{130} \\
(40)\end{array}$ \\
\hline & & & & EAU CLAIRE & $=$ & $\begin{array}{l}\text { SANDSTONE, } \\
\text { SIITSTONE, SHALE }\end{array}$ & $\begin{array}{l}300 \\
(900)\end{array}$ \\
\hline & & & & MT. SIMON & & SANDSTONE & $\begin{array}{l}1.250 \\
(300)\end{array}$ \\
\hline 丞 & 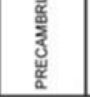 & 1 & - & - & & IGNEOUS BASEMENT & $\begin{array}{l}1000 \\
(>300)\end{array}$ \\
\hline
\end{tabular}

Figure 1. Stratigraphic column for Northern Illinois. Marked in blue, the Galena and Platteville and St. Peter formations make up the bulk of the bedrock landscape in the study area. The Glenwood formation was not observed in the study area. A regional contour of the Franconia formation is used in the discussion. (Willman, 1973; Willman and Kolata, 1978; Kolata and Graese, 1983). 


\section{Structure}

\section{Plum River Fault Zone}

The Plum River Fault Zone (PRFZ) extends 112 miles (180 kilometers) eastward from central Iowa into northern Illinois. The PRFZ disrupts Ordovician aged strata in northern Illinois (figures 2, 3) (Templeton and Willman, 1951; Kolata and Buschbach, 1976; 1978; Ludvigson and Bunker, 1989). Oriented approximately $\mathrm{N} 70^{\circ} \mathrm{E}$, high angle normal faults run the length of the zone with north displacement between 100 and 400 feet (30-121 meters) (Nelson, 1995). The fault zone is bounded by a northern syncline, with a southern dome and anticline (figures 2, 3). In addition, northwest-trending en echelon normal and reverse faults are present on the southern flanks of the fault zone (figures 2, 3; Willman and Templeton, 1951; Kolata and Buschbach, 1976; 1978). The timing and stress field responsible for the Plum River Fault Zone is not well established (Kolata and Buschbach, 1976; 1978; Ludvigson and Bunker, 1989; Nelson, 1995). Correlations of the strata north and south of the PRFZ indicate that faulting occurred sometime after the Silurian Period (Ludvigson and Bunker, 1989). Regional structure contour patterns of the Franconia formation indicate that deformation from the fault zone penetrates, at the minimum, Cambrian aged strata (figure 4; Kolata and Buschbach, 1983). It is accepted that the PRFZ and its associated structure was created by the reactivation of a basement penetrating fault (McGinnis and Heigold, 1976; Marshak et al., 2003; Nelson, 1995).

\section{Leaf River Anticline}

The Leaf River anticline an east-west trending footwall fold that is located along the eastern terminus of the PRFZ (Kolata and Buschbach, 1976; 1978). Being related to the PRFZ in time and space, the anticline was created by the propagation of a basement reactivated fault (Ludvigson and Bunker, 1989; Nelson, 1995; Marshak et al., 2003). Structure contour mapping 
of the Glenwood formation top (figure 3) indicate that the anticline is approximately 6 miles long (10 kilometers) with 85 feet (26 meters) of closure on the foot wall of the fault zone (Kolata and Buschbach, 1976; 1978). In outcrop, slickensides and small en echelon faults have been observed along the crest of the anticline (figure 3; Willman and Templeton, 1951). Due to the eastward increase in glacial overburden and erosion of the Glenwood formation, the geometry of the Leaf River anticline at the terminus Plum River Fault Zone is not known (figure 3; Kolata and Buschbach, 1976; 1978; Nelson, 1995).

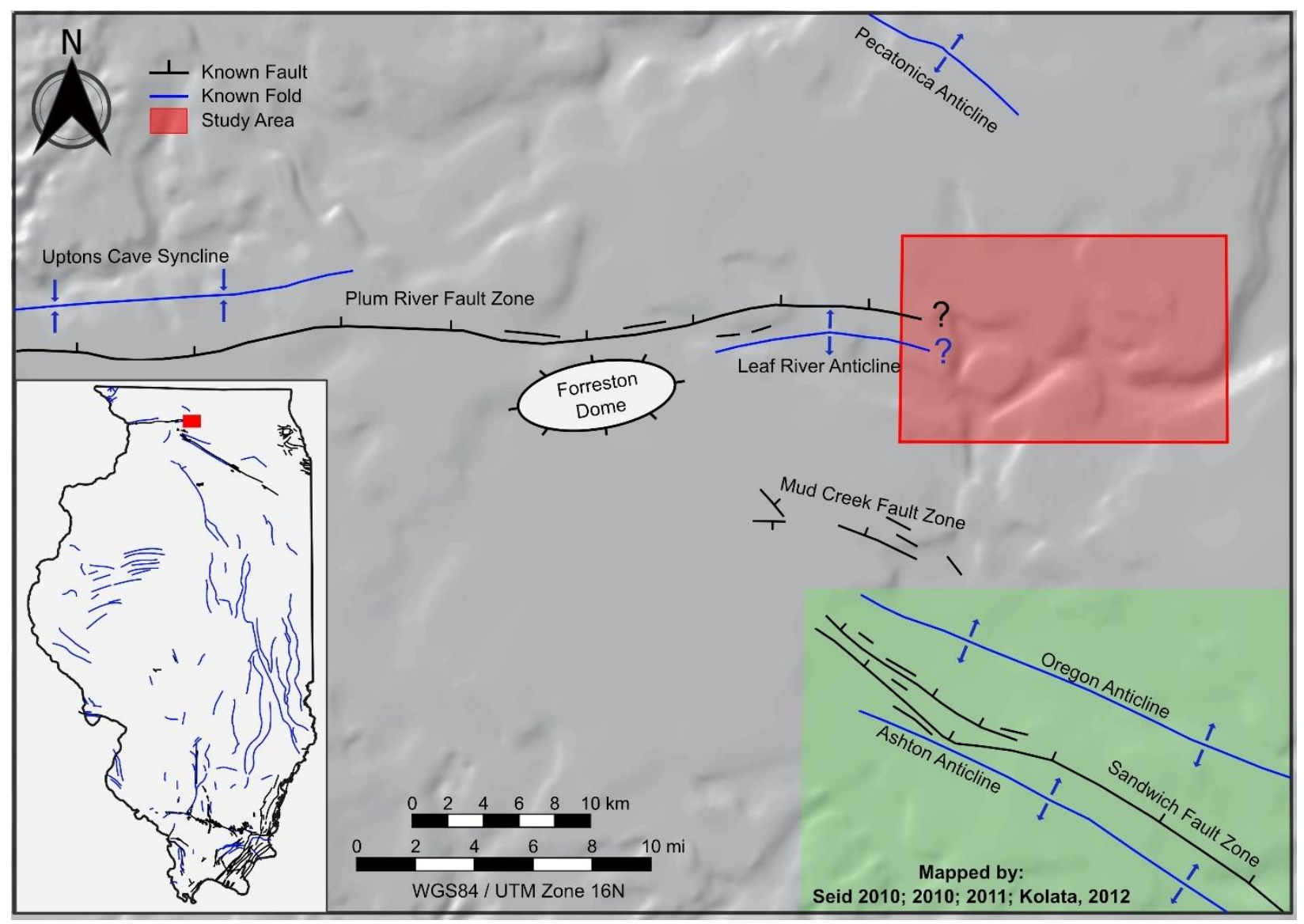

Figure 2. Bedrock structure in northern Illinois. The study area is outlined in red. STATEMAP quadrangles are outlined in green. 


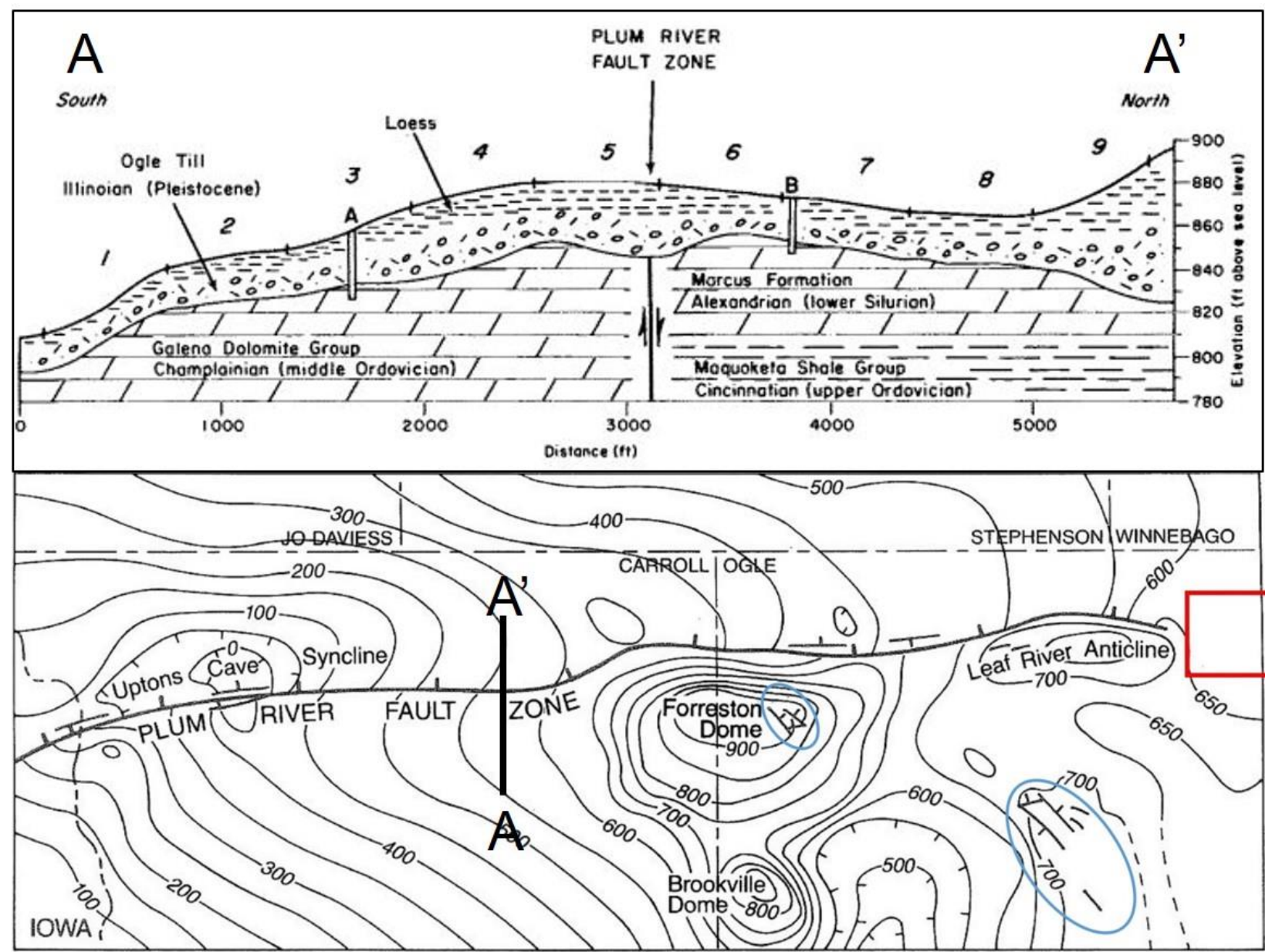

Figure 3. Modified from Kolata and Buschbach, 1976: Structure contour of the Glenwood Formation top and A-A' cross section of the PRFZ. Study area is outlined in red. Northeast and northwest trending en echelon faults outlined in blue. 


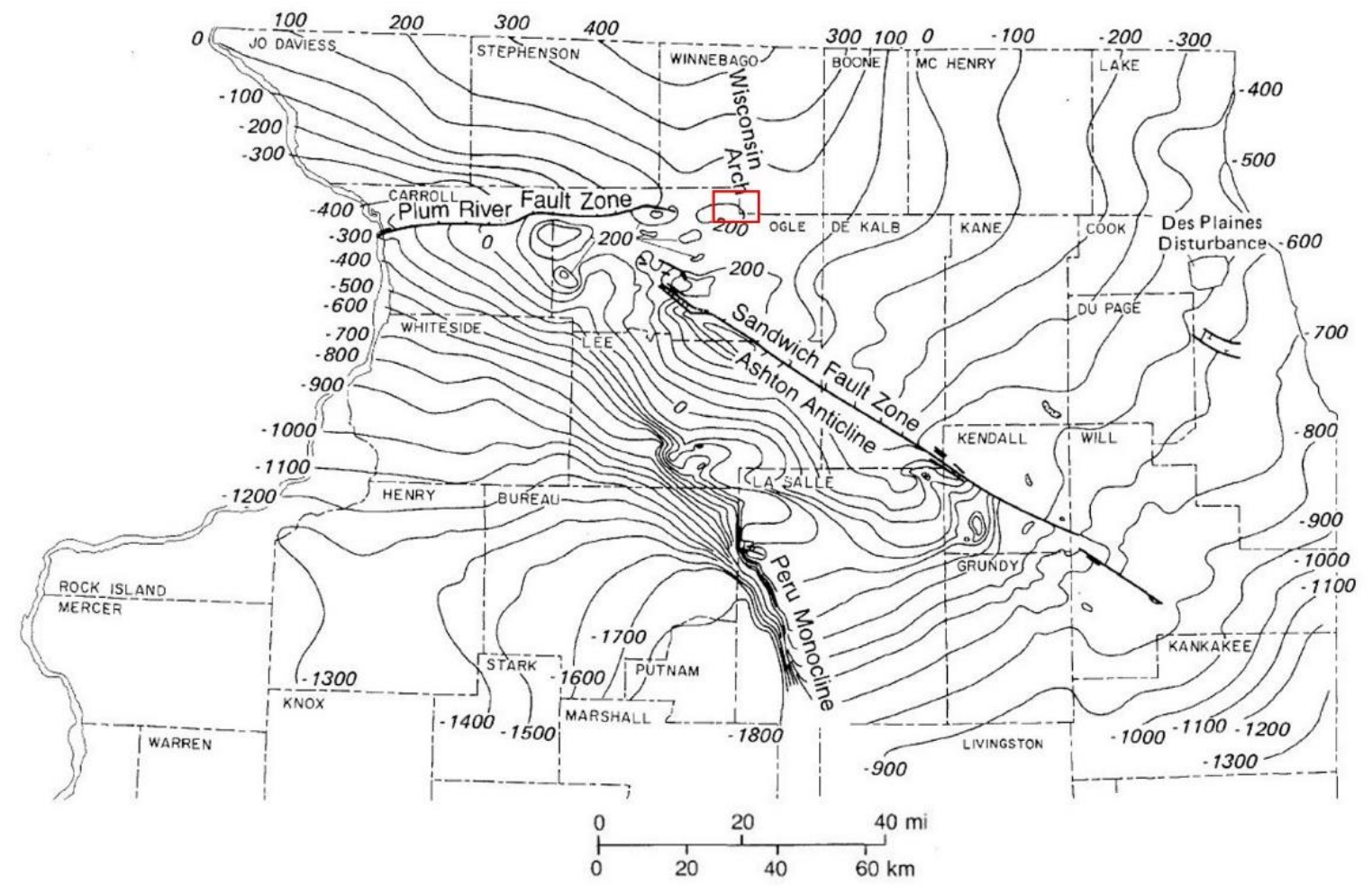

Figure 4. Modified from Kolata and Buschbach, 1983: Top of the Cambrian Franconia Formation with the study area marked in red. 


\section{Preglacial Paleogeography}

\section{Leaf River Paleovalley}

The Leaf River Paleovalley is a component of the preglacial drainage in northern Illinois (figure 5). The entrenchment of this feature began in the Cenozoic and was completed by the onset of the Pleistocene glaciations (Horberg, 1950). The local trend of the Leaf River Paleovalley was controlled by structure present at the terminus of the Plum River Fault Zone (figures 2, 3; Kolata and Buschbach, 1976; 1978; Anderson 2005). The paleovalley and its tributaries form a narrow bedrock gorge that is carved into the Galena, Platteville, St. Peter formations. Prior to the Pleistocene, the paleovalley drained eastward into the ancestral Rock Paleovalley (Horberg, 1950; Anderson, 2005)). During the Pleistocene, the feature was buried by approximately 250 feet (76 meters) of outwash. This glacio-fluvial activity reduced the drainage divide between the Rock and Leaf River paleovalleys and set the stage for the diversion of ancestral Rock River (figure 5; McGinnis 1968; Anderson 1988; 2005).

\section{Glacial Spillway}

A spillway is a secondary drainage channel that develops in response to massive outbursts of impounded water from failed ice damns (Kehew and Clayton, 1986; Cutler et al. 2002). These spillways reshape the preglacial landscape and affect the movement of ice and deposition of glacial sediments (Brown and Kennet, 1998; Curry and Yansa, 2004). In northern Illinois, the ancestral Rock River was repeatedly damned by ice in the Rock paleovalley during the Illinois Glacial Episode (Horberg, 1950; Anderson 1988). Failure of the ice damns released impounded meltwater that carved a spillway into the bedrock and diverted the Rock River to its current position (figure 5; Horberg, 1950; Horberg and Anderson, 1956; Anderson, 2005). 
After diversion, the spillway served as a conduit for meltwater with 50 to 100 feet (15-30 meters) of outwash sand deposited during the remainder of the Pleistocene. The bedrock gorge associated with the spillway is visible on the land surface, but the position of the interface between the Leaf River paleovalley and the spillway is obscured by the terraced outwash sediments (Anderson, 2005). Available mapping of the paleo topography in the region does not reveal the details of the geometry and orientation of the spillway (Horberg 1950; Horberg and Anderson, 1956; Anderson, 2005).

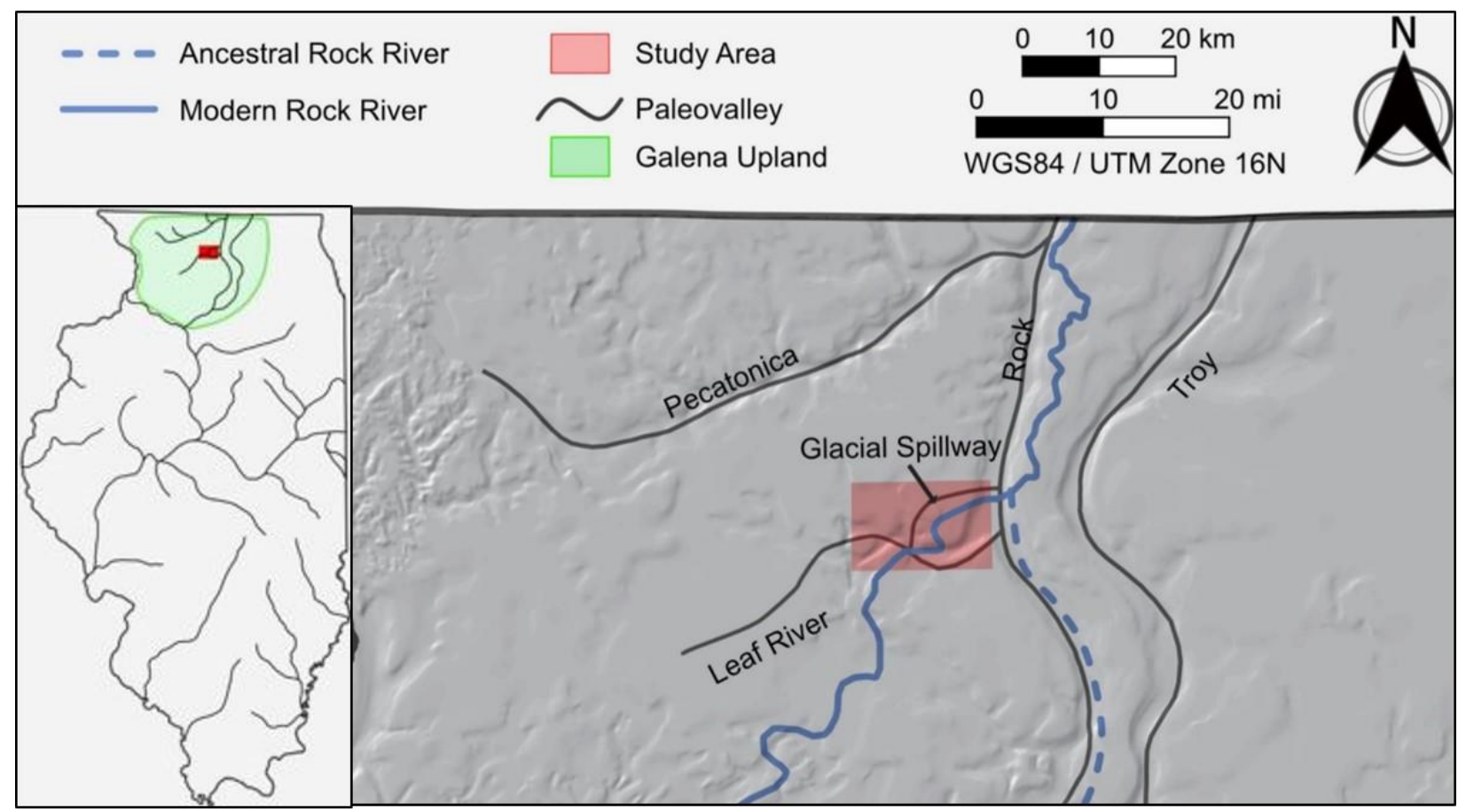

Figure 5. Paleogeographic map for the Galena Upland in Northern Illinois. The ancestral and modern positions of the Rock River are marked in blue. The approximate subsurface locations of paleo features are marked and labeled in black. The study area is shown in red. 


\section{Purpose}

Previous work indicates that the Leaf River Paleovalley and the spillway occur in proximity to the Leaf River anticline at the terminus of the Plum River Fault Zone (figures 2, 6) (Horberg, 1950; Kolata and Buschbach, 1976; 1978; Anderson, 2005). However, the relationship between the Leaf River anticline and the bedrock paleo topography have not been explored. The purpose of this study is to delineate the eastern structure of the Leaf River anticline and relate this structure to the development paleo topography in the study area. Public water well data and geostatistics will be used to construct elevation models of the bedrock paleo topography and the Leaf River anticline. Two geologic horizons were selected to capture the geometries of these subsurface features:

1. Paleo topography: Bedrock surface consisting of Galena, Platteville, and St. Peter formations.

2. Leaf River anticline: Top of the St. Peter Sandstone Mapping the topography of these two horizons will allow the trend and magnitude of the structure associated with the Leaf River anticline to be assessed. Additionally, these elevation models will allow for the direct comparison of the anticline to the orientation and dimensions of the Leaf River paleovalley and glacial spillway.

\section{Research Questions}

To guide this project, two research questions with specific hypotheses were developed to focus the interpretation of the structure and paleo topography revealed by the elevation models. The first research question focuses on the Leaf River anticline:

1. What is the subsurface geometry of the Leaf River anticline beyond the eastern terminus of the Plum River Fault Zone?

I hypothesize that the Leaf River anticline extends farther east than indicated by prior work (figure 2; Horberg, 1950; Kolata and Buschbach, 1976; 1978). Mapping the elevation of the 
conformable St. Peter top will show that the anticline extends farther east with extended closure at a higher subsurface elevation. The position of this anticline also supports the eastward extension of the Plum River Fault Zone.

The second research question focuses on the relationship between the Leaf River anticline and the paleo topography in the study area:

2. How did the presence of the Leaf River anticline control the evolution the paleo topography and diversion of the ancient Rock River?

I hypothesize that the Leaf River anticline created an east-west oriented topographic high that controlled the entrenchment of the Leaf River Paleovalley and glacial spillway indicated by prior works (Horberg, 1950; Horberg and Anderson, 1956; McGinnis, 1968; Anderson, 1988; 2005). The Leaf River Paleovalley first formed on topographic low on the southern flank of the anticline. Later, the glacial spillway developed from antecedent drainage on the north side of the anticline. The failure of an ice damn in the Rock Paleovalley released impounded meltwater that cut through the axis of the anticline and connected the Leaf River Paleovalley with the glacial spillway, permanently diverting the ancestral Rock River.

\section{Study Area}

Geographically, the subsurface structure and paleo topography targeted by this study is located at the Ogle and Winnebago county line in Northern Illinois (figure 6). Bedrock outcrops of Galena Dolomite are only present in quarries or along the Rock River (figure 7). The Platteville and St. Peter are only present in the subsurface (Willman and Kolata 1978; Kolata and Buschbach, 1983). The modern Rock River flows to the southwest before making a sharp westerly bend (figure 6). This change of direction marks the transition in Rock River path from the glacial spillway to the Leaf River Paleovalley (Anderson, 2005). Based on the dimensions 
and locations (figures 2,6 ) of the target features, a six by ten mile (10 by 16 kilometers) domain was constructed for elevation modeling and mapping (figure 6). With the St. Peter Formation being the primary aquifer in the region, this community of Byron, provides a dense sample set of 2,500 well logs for elevation modeling (figure 6; Vishocky et al., 1985; Abrams et al., 2016).

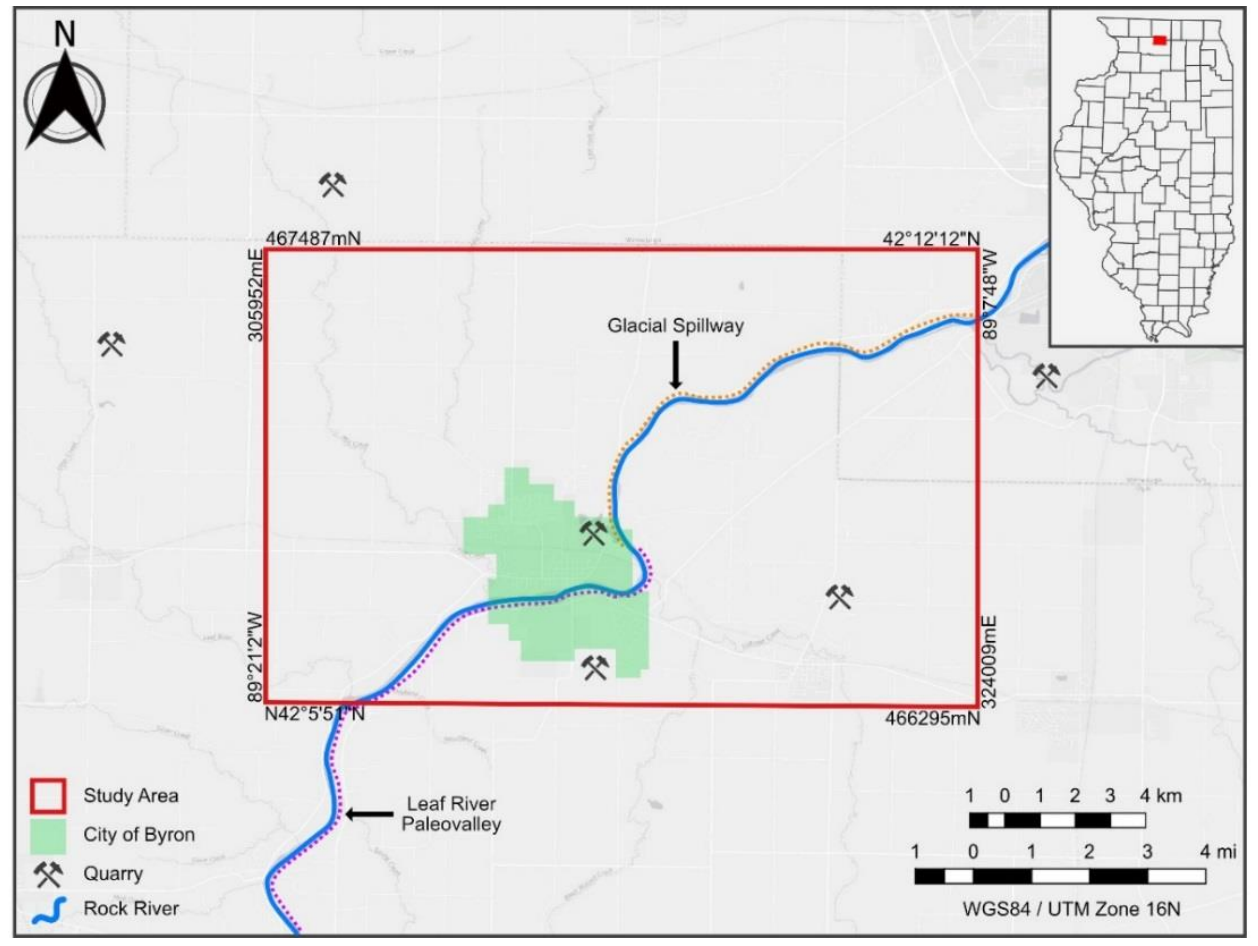

Figure 6. The geographic location of the study area. 


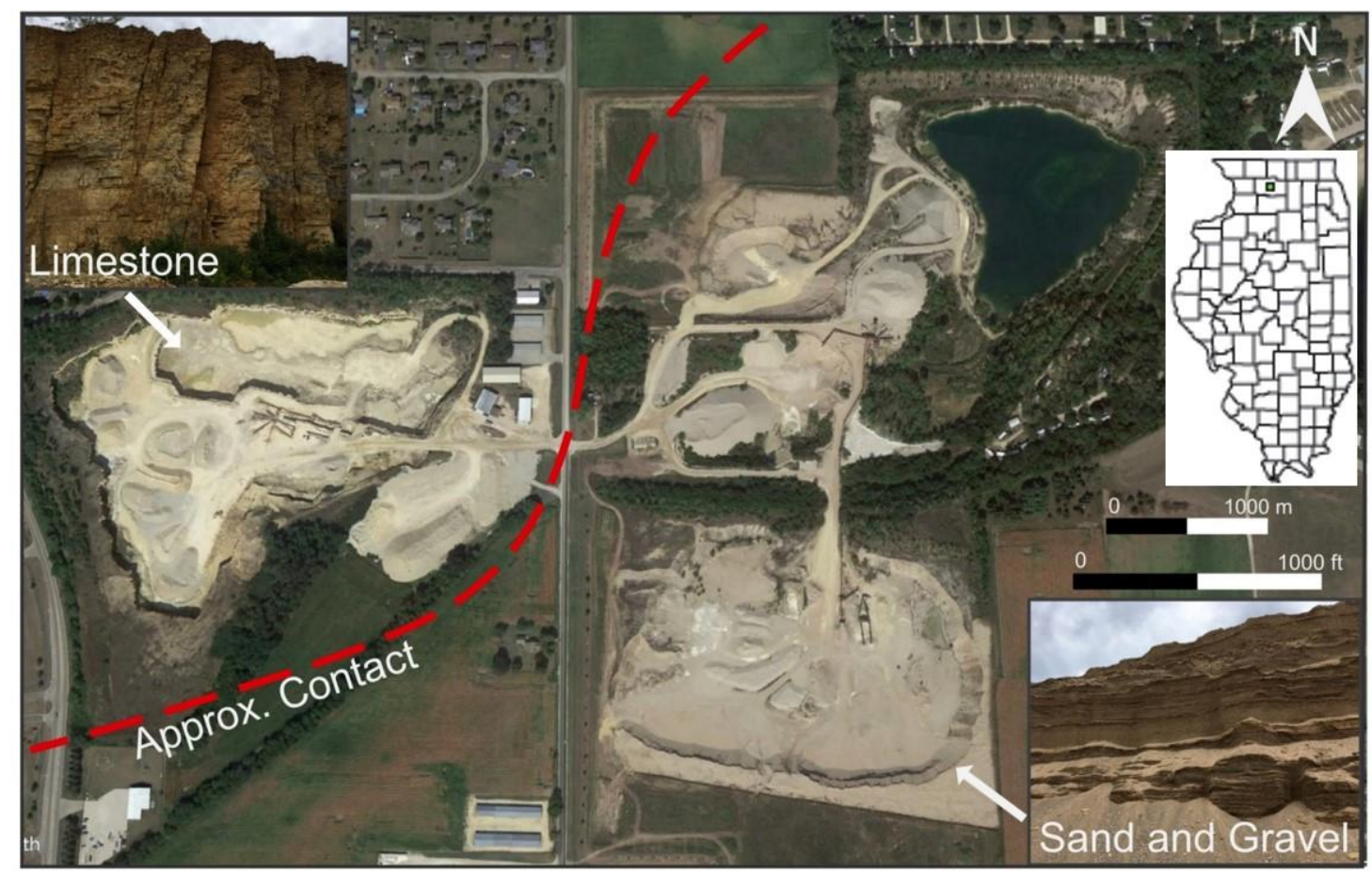

Figure 7. Aerial imagery showing bedrock exposed in quarries along the Rock River 


\section{CHAPTER II: METHODS}

\section{Geologic Database}

All the geologic data used to model the elevation of the bedrock surface and the St. Peter top were derived from public water well logs. These logs contain stratigraphic, location, and elevation data necessary to construct accurate subsurface interpretations. Due to minimal state requirements and driller competence, the geologic information recorded on these logs often contain errors (Visocky et al., 1985; Barnhardt, 2000; Abrams et al. 2015). In addition, the drilling of water wells is controlled by the needs of private citizens, larger community, and industry. City limits and other forms of infrastructure create an uneven and clustered spread of geologic data across a domain (Barnhardt, 2000; Chung and Rogers 2012; Van Hoesen ,2014).

The driller's logs compiled in the geologic database were manually sampled from the Illinois State Geological Survey's Illinois Water Well Interactive Database (ILWATER). ILWATER is a public information repository for municipal and private wells drilled from 1985 to the present. Each well $\log$ is a digitized version of the report recorded during the drilling of a water well. The reports contain the well identification number, geographic coordinates in decimal degrees, and the rock units encountered during drilling given in intervals measured in feet (Barnhardt 2000; Abrams et al. 2015).

\section{Data Selection}

A selection procedure based on Illinois State Geological Survey (ISGS) standards was used to manually verify an approximate starting set of 2,500 water well records present in the study area (Barnhardt 2000; Abrams et al. 2015). The procedure is a two-step process that confirms geographic location and checks the observed lithology with published descriptions. The assessment procedure was carried out on every individual well in the ILWATER database 
located in the study area. If a sampled well log did pass the selection it was excluded in the final dataset used to generate the elevation models.

Frist, the geographic location of a well is confirmed with basic GIS analysis. Within the map space, the reported positon of the well is overlain on aerial imagery and local property address vectors. This approach is used to cross reference the geographic coordinates and street address reported on the driller's log with those listed by the county government. With the location confirmed, the stratigraphy recorded on the log was compared to published geologic descriptions of this area. These descriptions were drawn from bulletins, project reports and local geologic maps published by the ISGS (Willman and Frye; 1970; Willman and Kolata; 1978; Visocky et al., 1985; Seid, 2010; 2010; 2011; Kolata, 2012).

The recorded lithology in the well log should reflect the local sequence of glacial drift, dolomite, and sandstone. The expected geology relative to the position of the well is also evaluated. For example, if the well is located at or near a known bedrock valley, a thick interval of sand and gravel should be recorded on the driller's log. Conversely, if the well is located on an upland surface where only thin veneer of till is present, this should be reflected on the log. If a well log passes both the location and stratigraphic assessment, then the water well log is deemed reliable and added to the geologic database.

\section{Data Input}

After assessment, each selected well was formatted for input into the project geologic database. The key geologic and geographic data were extracted from the well log and inserted into tab delimited text file under the following header variables:

1. Well Identification number (API)

2. Geographic Coordinates given in decimal degrees (latitude and longitude)

3. Depth drilled to top of bedrock surface (ft.)

4. Depth drilled to top of St. Peter sandstone (ft.) 
Once the key data from every selected well is compiled the database is ready for the next stage of processing. In preparation for processing the following empty header variables are added to the text file:

1. UTM Coordinates (Easting ft. and Northing ft.)

2. Ground Surface Elevation (ft.)

3. Horizon Elevation for the bedrock surface (ft.)

4. Horizon Elevation for the top of the St. Peter Sandstone (ft.)

\section{Data Processing}

A series of basic GIS operations are carried out on each well log in the database to standardize the coordinate system and assign ground elevations. The geographic coordinates were transformed to a projected coordinate system (WGS 1984 UTM Zone 16N) to allow well locations to be listed in feet. With a set projection, ground surface elevation at each location was sampled in meters from a USGS 10m DEM and then converted to feet using a point selection query. Finally, the UTM coordinates and ground surface elevations were assigned to the corresponding header variables in the database with a table join.

The horizon elevations for the bedrock surface and St. Peter top were computed by subtracting the depth drilled to contact from the ground surface elevation from at each well point. The outputs from this operation were recorded under a new header variable and statistically summarized. After selection, formatting, and processing a geostatistical approach was used to model the elevations of the target horizons using the observed elevations in this dataset.

\section{Geostatistics}

\section{Regionalized Variable}

A central concept of geostatistics is the regionalized variable. The regionalized variable is a natural function that describes the change of a phenomenon with respect to geographic position 
(Hengal, 2009). For this project the elevation above sea level of a geologic horizon is the regionalized variable. The regionalized variable has properties of both a random and deterministic quantity. As such, a probalistic approach can be employed to estimate the regional variable using only observations taken from known locations (Olea, 1999; Davis, 2002).

\section{Semivariance}

The basic geostatistical measure of the regionalized variable is the semivariance. This measure describes the change in variance between pairs of observations with respect to separation distance. Formally defined, the semivariance is the sum of the squared differences between point pairs separated by some distance and divided by the number of possible point pairs (Olea, 1999; Davis, 2002):

$$
\gamma_{h}(x)=\frac{\sum_{i}^{n-h}\left(x_{i}-x_{i+h}\right)^{2}}{2 n}
$$

The semivariance for pairs of observations is computed at a range of distances $(h)$, or "lags", within the domain. The lag dictates what pairs of observations will be used to compute the semivariance within a given separation distance. Computing semivariances for several lags and then plotting the results against separation distance generates the variogram. The variogram displays spatial variance of observations separated by large and small distances in the dataset (Olea, 1999; Davis, 2002).

\section{Modeled Variogram}

The semivariances plotted on the variogram only apply to the discrete lag intervals. To compute semivariances of point pairs at possible separation distances, the variogram is modeled with a continuous function. These functions are manually fitted to the variogram to smoothly mirror discrete semivariances (Olea, 1999; Davis, 2002). The modeled variogram provides a continuous measure of semivariance for all separation distances in the domain. This will allow 
for the computation of semivariance for point pairs where there is no elevation observation. The ability to compute semivariances between point pairs of known and unknown observations is a critical component in the overarching geostatistical estimation of surface elevation (Olea, 1999; Davis, 2002).

\section{Ordinary Kriging}

The elevation at an unknown location can be interpolated with ordinary kriging (Davis 2002). A classic geostatistical tool, this procedure is a class of linear regression that interpolates the regionalized variable at an unsampled location from known observations in the same neighborhood (Hengal, 2009). Ordinary kriging has three primary requirements (Olea, 1999; Davis, 2002):

1. Sample set of greater than 30 observations

2. Regional variable is a random function with a stationary mean

3. Modeled semivariances have a clear structure (i.e. the variogram has a sill)

Given that the requirements are satisfied, the unknown elevation at a target location, given as $\left(x_{0}\right)$, can be computed using the surrounding observed elevations weighted by the semivariances. The kriging model creates a system of equations that are solved using matrix algebra (Olea, 1999; Davis, 2002).

First, the kriging weights $(\Lambda)$, need to be estimated by pre-multiplying the inverse matrix of the observed semivariances by the modeled semivariances at the target location (Olea, 1999; Davis, 2002):

$$
\Lambda=W^{-1} B=\left[\begin{array}{cc}
\gamma\left(x_{i} x_{i}\right) & \ldots \\
\cdots & \gamma\left(x_{k} x_{k}\right)
\end{array}\right]^{-1}\left[\begin{array}{c}
\gamma\left(x_{0} x_{i}\right) \\
\gamma\left(x_{0} x_{k}\right)
\end{array}\right]
$$

Once the kriging weights, $(\Lambda)$ have been computed, they are used to post-multiply the transpose of the observed elevations $(Y)$ and reduce the matrices to a linear equation. From the linear equation, the unknown elevation $\left(x_{0}\right)$ is directly estimated at the target location by 
summing the products of the known elevations and the kriging weights (Olea, 1999; Davis, 2002):

$$
Z\left(x_{0}\right)=\left[\begin{array}{c}
Z\left(x_{i}\right) \\
\cdots \\
Z\left(x_{k}\right)
\end{array}\right]^{T} \Lambda=Y^{T} \Lambda
$$

The power of ordinary kriging is that it does not require the population mean of the regionalized variable to be known in advance to make predictions (Herzfield et al., 1993; Zimmerman and Ruggles, 1999). As such, elevation at unknown points can be modeled outside of the range of observed values (Olea, 1999; Davis, 2002). This inherent flexibility allows for the modeling of elevation and prediction of geologic surfaces that are not constrained by the bounds of the sample set (Chung and Rodgers, 2012; Van Hoesen, 2014).

\section{Uncertainty Analysis}

As a class of linear regression, modeled elevations produced by ordinary kriging can be directly compared to observed elevations at the same location (Olea, 1999; Davis, 2002). The residuals between the observed and estimated elevations can be graphically and statistically evaluated to assess the reliability of the structure contours. Using basic R programming, a set of statistical tools will be used to that test the ability of the Kriging model to honor observed geologic data:

1. Root Mean Square Error (RMSE)

2. Coefficient of Determination $\left(r^{2}\right)$

3. F-Test

\section{Root Mean Square Error}

The Root Mean Square Error quantifies the dispersion between elevation residuals with a positive value in the same unit of as the structure contour map. Formally defined, RMSE is the 
square root of the sample standard deviation of the residuals between predicted $\left(x_{i}\right)$ and observed elevations $\left(x_{o}\right)$ at a given location (Olea, 1999; Davis, 2002):

$$
R M S E=\sqrt{\frac{\sum_{i=1}^{n}\left(x_{o}-x_{i}\right)^{2}}{n}}
$$

The closer the RMSE value is to zero, the smaller the error between model estimates and observed elevations. A small RMSE value relative to the range of sample elevations indicates that Ordinary Kriging model estimated elevation with minimal error (Olea, 1999; Davis, 2002):

\section{Coefficient of Determination}

The Coefficient of Determination $\left(r^{2}\right)$ measures the proportion of variance in the observed elevations that is predicted by the modeled elevations. Formally defined, $r^{2}$, is the sum of the squared residuals divided by the sum of squared observations and normalized from one (Olea, 1999; Davis, 2002):

$$
r^{2}=1-\left(\frac{\sum_{i=1}^{n}\left(\hat{x}_{i}-\bar{x}\right)^{2}}{\sum_{i=1}^{n}\left(x_{i}-\bar{x}\right)^{2}}\right)
$$

Given as a percentage, the $r^{2}$ value indicates the correlation between the interpolated and observed elevations. When the variance between elevation residuals is minimized, the $r^{2}$ value will approach one. An $r^{2}$ value close to one indicates that the Kriging model accurately approximated the observed elevations (Olea, 1999; Davis, 2002).

\section{F-Test}

The F-test is used to statistically quantify the strength of the correlation between interpolated and observed elevations by comparing the residual variances to a probability distribution of variance ratios (Olea, 1999; Davis, 2002). The goal of this test is to confirm the correlation between observed and modeled elevations is statistically significant with the following hypothesis test: 
1. Ho: the residual variance between the observed and estimated observations are statistically similar.

2. $\mathrm{H}_{\mathrm{A}}$ : the variances between observed and estimated elevations have no relationship.

The test produces a p-value that is compared to an alpha of 0.05 at a $95 \%$ confidence interval. If the p-value is less than the alpha, the null hypothesis $\left(\mathrm{H}_{\mathrm{o}}\right)$ is accepted. The null hypothesis provides statistical evidence bounded by a confidence interval that the correlation between observed and modeled elevations are similar (Olea, 1999; Davis, 2002).

\section{Computer Based Modeling}

The management of the geologic database, construction of a Kriging model, and evaluation of uncertainty is best suited to computer based tools. The selection and formatting of geologic data was conducted with Quantum G.I.S. and M.S. Excel. Golden Software's Surfer 13 was used to interpolate elevation grids and plot derivative contour maps. The uncertainty analysis was carried out with basic $\mathrm{R}$ programming. The computer based approach allows a worker to focus on the production of reliable structure contour maps and the interpretation of results. 


\section{CHAPTER III: RESULTS}

\section{Geologic Database}

\section{Observed Wells}

The selection and processing of driller's logs identified 373 reliable wells for use in the structure contour mapping of the study area. In addition to the wells selected from ILWATER, 27 synthetic data points were converted from wells drilled into outwash sands filling paleo valleys in the study area. The combined set of wells in geologic database were classified into three categories:

1. Wells that were drilled through the bedrock surface to the top of the St. Peter Sandstone

2. Wells that were only drilled through the bedrock surface

Summary statistics for each horizon was computed with R and summarized in (table 1).

Of the 373 total wells, only 343 and reached the top of the St. Peter Sandstone. The approximate mean elevation for the St. Peter Top was 619 feet (118 meters) with a standard deviation of 60 feet (18 meters) (table 1). All 373 wells in the database drilled through the bedrock surface. The approximate mean elevation for this horizon was 728 feet (222 meters) with a standard deviation of 77 feet (23 meters) (table 1).

\section{Synthetic Wells}

In the deepest sections of the paleovalleys, water wells were only drilled into glacial sands the fill the features. When compared to the expected geology, the sand wells were drilled just short of the bedrock surface. To provide a measure of elevation control in the paleovalleys, the approximate bedrock elevation was projected to the sand wells from nearby bedrock surface wells. A group of 27 sand wells were converted into synthetic bedrock surface wells with a mean of 540 feet (164 meters) and standard deviation of 43 feet (13 meters) (table 1). 
Table 1

Summary statistics for wells in the geologic database.

\begin{tabular}{lccccccccc}
\hline Horizon & $\begin{array}{c}\text { Count } \\
(\mathrm{n})\end{array}$ & $\begin{array}{c}\text { Mean } \\
(\mathrm{ft})\end{array}$ & $\begin{array}{c}\text { Mean } \\
(\mathrm{m})\end{array}$ & $\begin{array}{c}\text { SD } \\
(\mathrm{ft})\end{array}$ & $\begin{array}{c}\text { SD } \\
(\mathrm{m})\end{array}$ & $\begin{array}{c}\text { Min } \\
(\mathrm{m})\end{array}$ & $\begin{array}{c}\text { Min } \\
(\mathrm{m})\end{array}$ & $\begin{array}{c}\text { Max } \\
(\mathrm{ft})\end{array}$ & $\begin{array}{c}\text { Max } \\
(\mathrm{m})\end{array}$ \\
\hline Bedrock & 373 & 727.8 & 221.8 & 77.1 & 23.5 & 492.3 & 150.1 & 849.4 & 258.9 \\
St. Peter & 343 & 619.0 & 188.7 & 59.3 & 18.1 & 492.3 & 150.1 & 760.5 & 231.8 \\
Synthetic & 27 & 540.4 & 165 & 43.4 & 13.2 & 505.0 & 153.9 & 625.0 & 190.5 \\
\hline
\end{tabular}

\section{Model Domain}

Using the geologic database, a model domain was constructed in Surfer to assign a coordinate system, plot wells, and set spatial boundaries (figure 8). The coordinate system was set to UTM Zone 16N for well locations and NAVD 1988 was used for horizon elevations. Imperial units (feet and miles) where selected for all horizontal and vertical measurements. The chosen spatial datum and measurement system was used to maintain consistency between publications and this project.

\section{Domain Construction}

The model domain was created using the maximum spatial limits of the plotted wells (figure 8). To encompass all data points, a six by ten mile (10 by 16 kilometers) rectangular boundary was set around the observed wells. Boundary limits where created at the outermost edges of the domain with blanked grid cells. The model domain was then filled with a regularly spaced grid of 166,848 unknown elevation cells. Each grid cell was assigned 100 by 100 foot dimensions ( 30 by 30 meters) with the elevation node at the center of the object. 


\section{Geologic Control}

Plotting the observed wells identified zones of varying data control within the study area (figure 8). Most the observed wells are clustered in the southern and center sections of the study area. In the extreme north, west, and east the frequency of observations diminishes. Of the 373 total plotted wells, only 343 penetrate the bedrock surface and the St. Peter horizon. This reduces coverage and control of the St. Peter horizon in the northern and eastern reaches of the area. The synthetic wells follow the confines of known buried features, providing measured coverage for bedrock surface elevations at these locations.

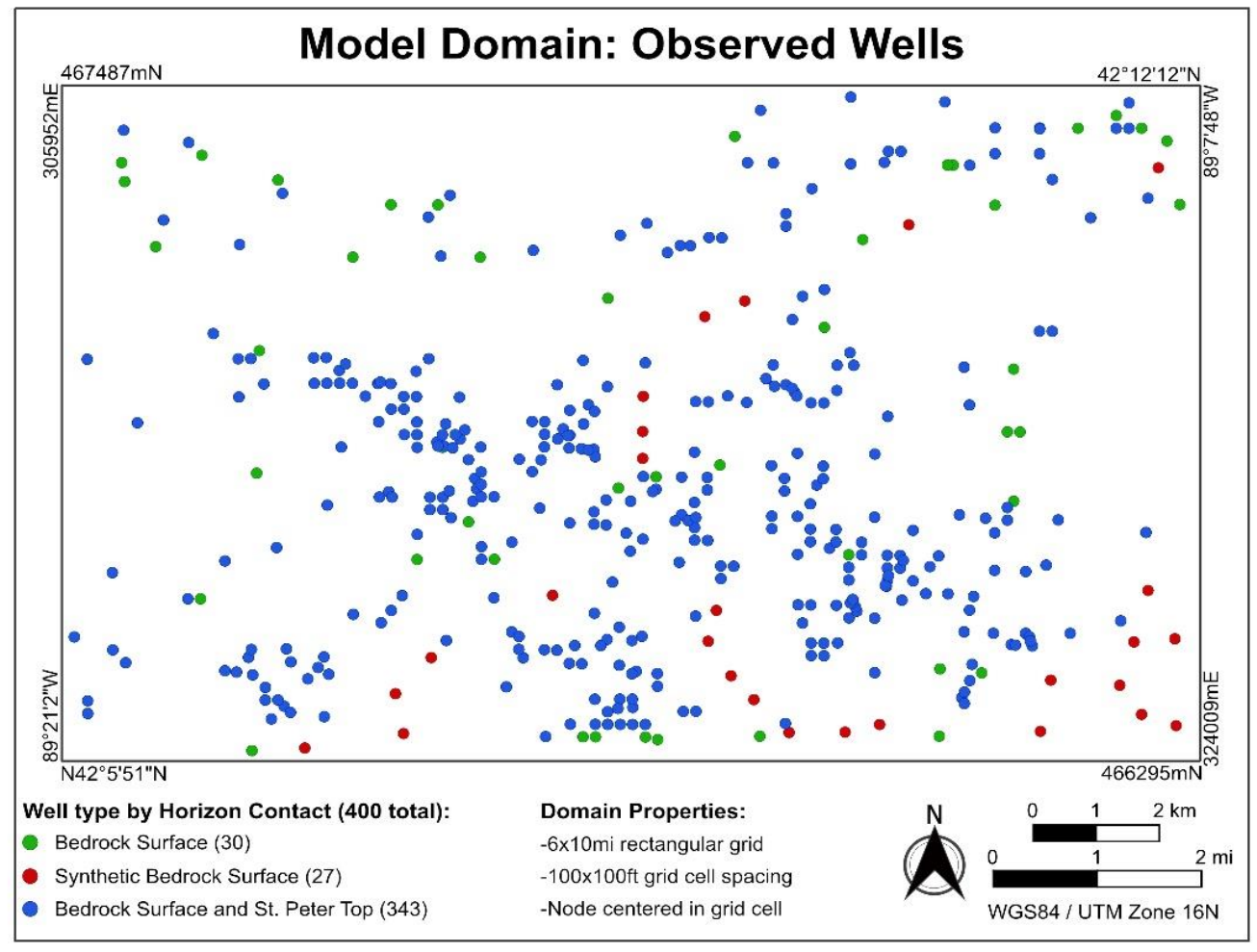

Figure 8. Model domain and wells used for elevation modeling.

\section{Uncertainty Analysis}

Before interpretation, the accuracy of the elevation models was assessed to verify that the predicted elevations honored the observed geologic data. The interpolated elevation residuals were evaluated to determine the significance of errors produced by ordinary kriging. This 
included examining the correlation and variance between the observed and interpolated elevations for both horizons within the domain.

\section{Root Mean Square Error}

The computed Root Mean Square Errors for the bedrock surface and the St. Peter top provided a direct measure of the accuracy of the elevation models. For each grid cell that contained a well point, the estimated elevation was directly compared to the observed elevation by computing the root mean square error and plotting the residuals. Respectively, the computed RMSE was approximately \pm 19 feet ( \pm 6 meters) and \pm 16 feet $( \pm 5$ meters) for the bedrock surface and St. Peter Top (table 2).

The observed elevations were plotted against the modeled elevations to provide a visual measure of the dispersions of errors in each horizon (figure 9). The residual plots indicate that the greatest interpolation errors occurred between 525-600 feet (160-183 meters) for the St. Peter top and between 600-750 feet (183-229 meters) for the bedrock surface. In the high error sections, the kriging model over predicted St. Peter top elevations and under predicted bedrock surface elevations.

\section{Coefficient of Determination}

The coefficient of determination $r^{2}$ for each horizon was computed and submitted to an F-test to quantify the linear correlation between the estimated and observed elevations (figure 9). Both horizons passed the F-test with an $r^{2}$ of $0.96(\alpha=0.05, \mathrm{p}<0.00)$ for the bedrock surface and $0.93(\alpha=0.05, \mathrm{p}<0.00)$ for the St. Peter Top (table 2$)$. This indicates that $96 \%$ and $93 \%$ of the observed residual variance was predicted by the estimated elevations in each horizon. Considering the $r^{2}$ and F-test results, there is a significant relationship between the estimated and observed elevations for each horizon. 
The $r^{2}$ and F-test quantified the strength of the linear relationship between the observed and modeled elevations in both horizons (figure 9). The statistically significant $r^{2}$ of 0.96 for the bedrock surface and 0.94 for St. Peter top indicate a strong linear correlation between the observed and modeled elevations (table 2). Even with the dispersion of errors (figure 9), the residual variance was minimized to maintain a tight correlation between the observed and modeled elevations. These results show that the kriging model honored the geologic data and produced statistically admissible elevation model for both the St. Peter top and the bedrock surface.

Table 2

Uncertainty analysis results for estimated elevations.

\begin{tabular}{lcccccc}
\hline Horizon & $\begin{array}{c}\text { RMSE } \\
( \pm \mathrm{ft} .)\end{array}$ & $\mathrm{r}^{2}$ & P-Value & $\alpha$ & Confidence & $\begin{array}{c}\text { Accept } \\
\mathrm{H}_{0}\end{array}$ \\
\hline Bedrock & 18.59 & 0.96 & $2.2 \mathrm{e}-16$ & 0.05 & $95 \%$ & Yes \\
St. Peter & 16.48 & 0.93 & $2.3 \mathrm{e}-16$ & 0.05 & $95 \%$ & Yes \\
\hline
\end{tabular}

Residual Plot: Bedrock Surface

Residual Plot: St. Peter Top
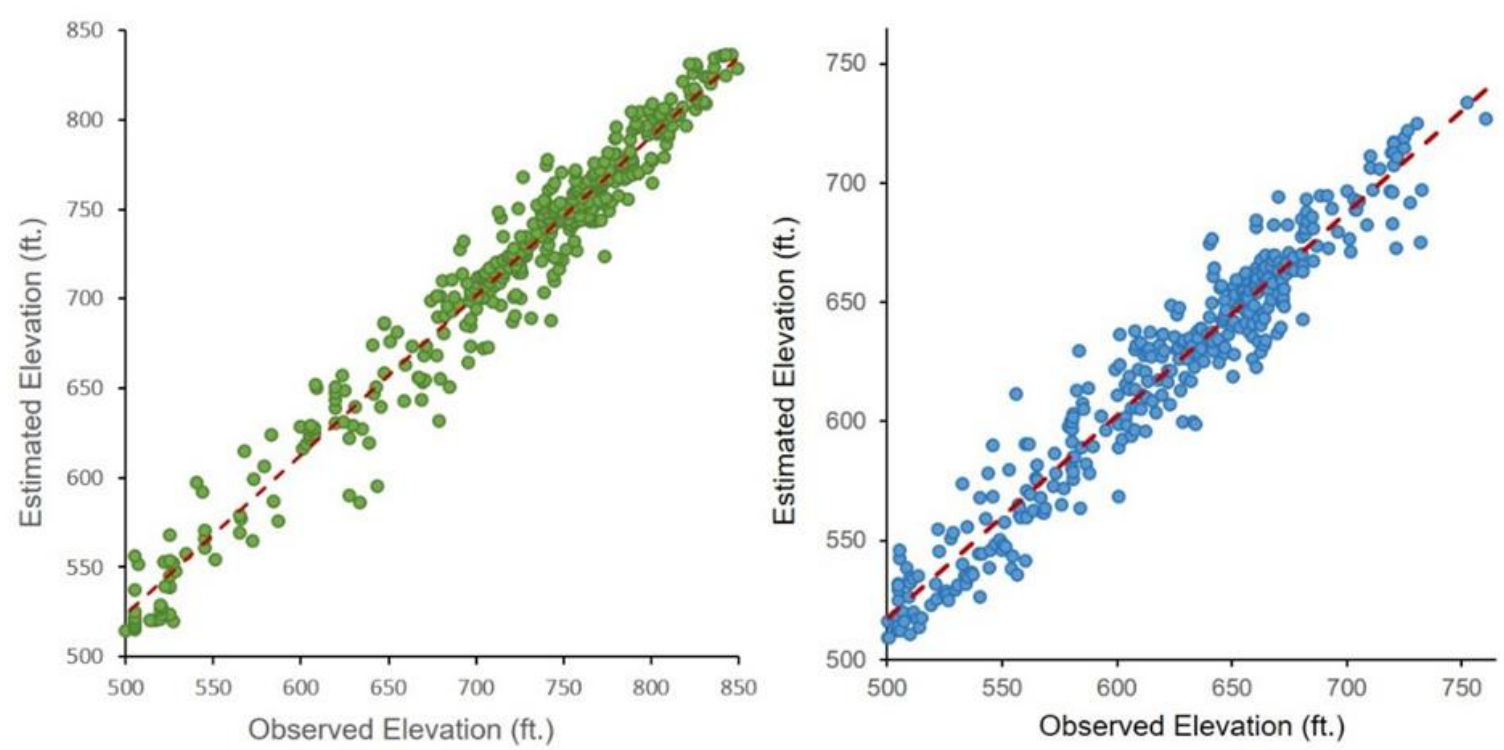

Figure 9. Residual plots for the Bedrock surface and St. Peter top. 


\section{Plotting Elevation Models}

After statistical qualification, the elevation models for the bedrock surface and St. Peter top was contoured and colorized using Surfer's plotting tools. Contours for each horizon were drawn with a 20 foot ( 6 meter) interval. Elevation contours for both horizons were plotted using the same color coded scale. A common color scale for both elevation grids allows the vertical separation between horizons to be evaluated visually in the map space. This allows for the identification of shared features that are otherwise obscured by glacial drift and overburden.

\section{St. Peter Top Contour Map}

The elevation model of the St. Peter top represents the stratigraphic contact between the St. Peter Formation and the overlaying Galena and Platteville Groups (figure 1). Being lower in the section, this contact is the ideal horizon to model the elevation of the Leaf River anticline. The colored contour map of the St. Peter top revealed an eight mile (13 kilometer) long structural high between 600-720 feet (183-219 meters) of elevation (figure 10). Oriented at approximately $\mathrm{N} 70^{\circ} \mathrm{E}$, this feature gently plunges from the southeast and tightens to closure at approximately 700 feet (213 meters) (figures 10, 11). The low channelized contours between 500-600 feet (152183 meters) are the floors of the glacial spillway and Leaf River paleovalley carved into the bedrock surface (figures 10, 11; Horberg 1950; Anderson, 2005). 


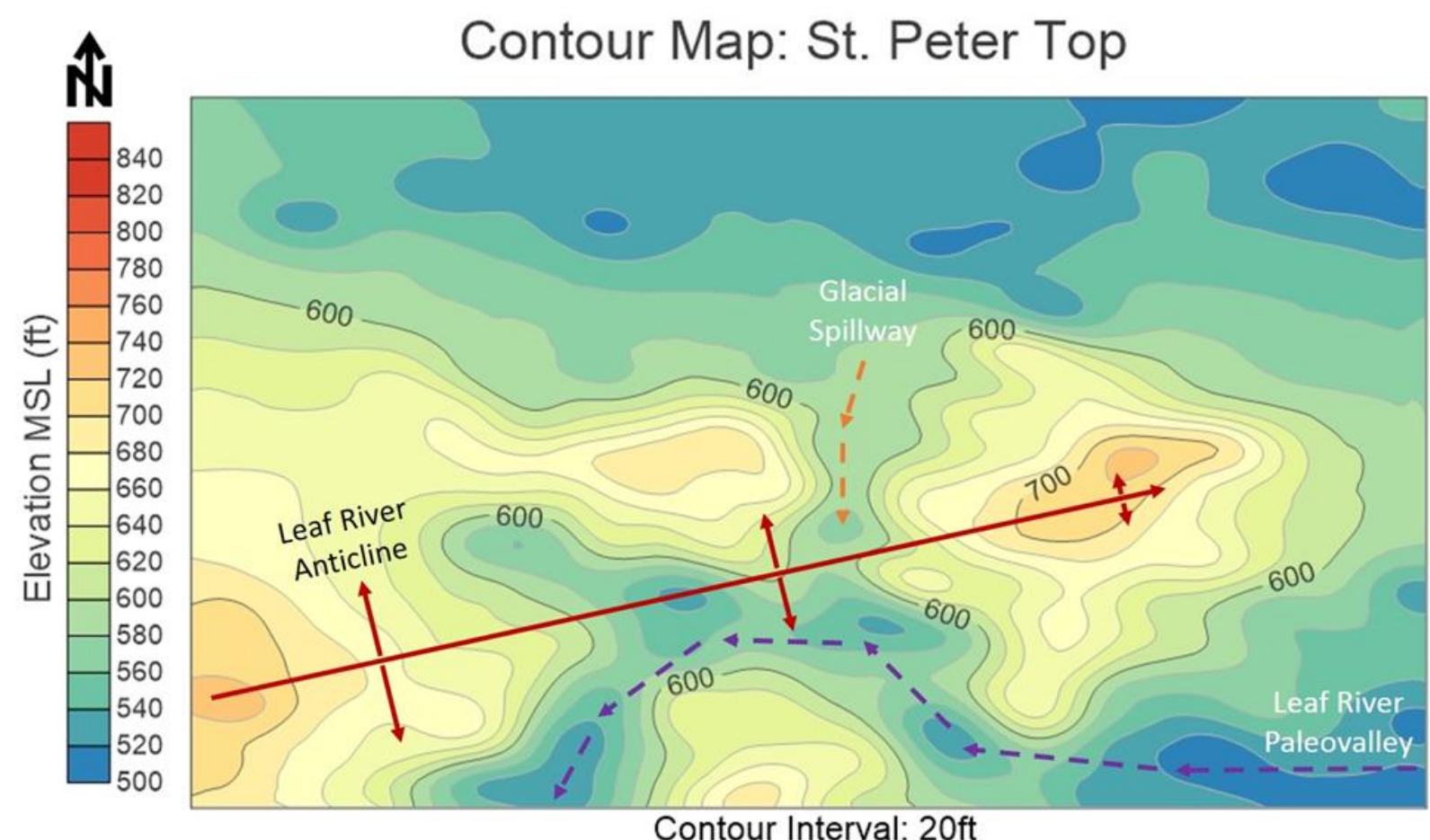

Figure 10. Elevation contour map of the St. Peter Top. The orientation of the Leaf River Anticline is marked in red.

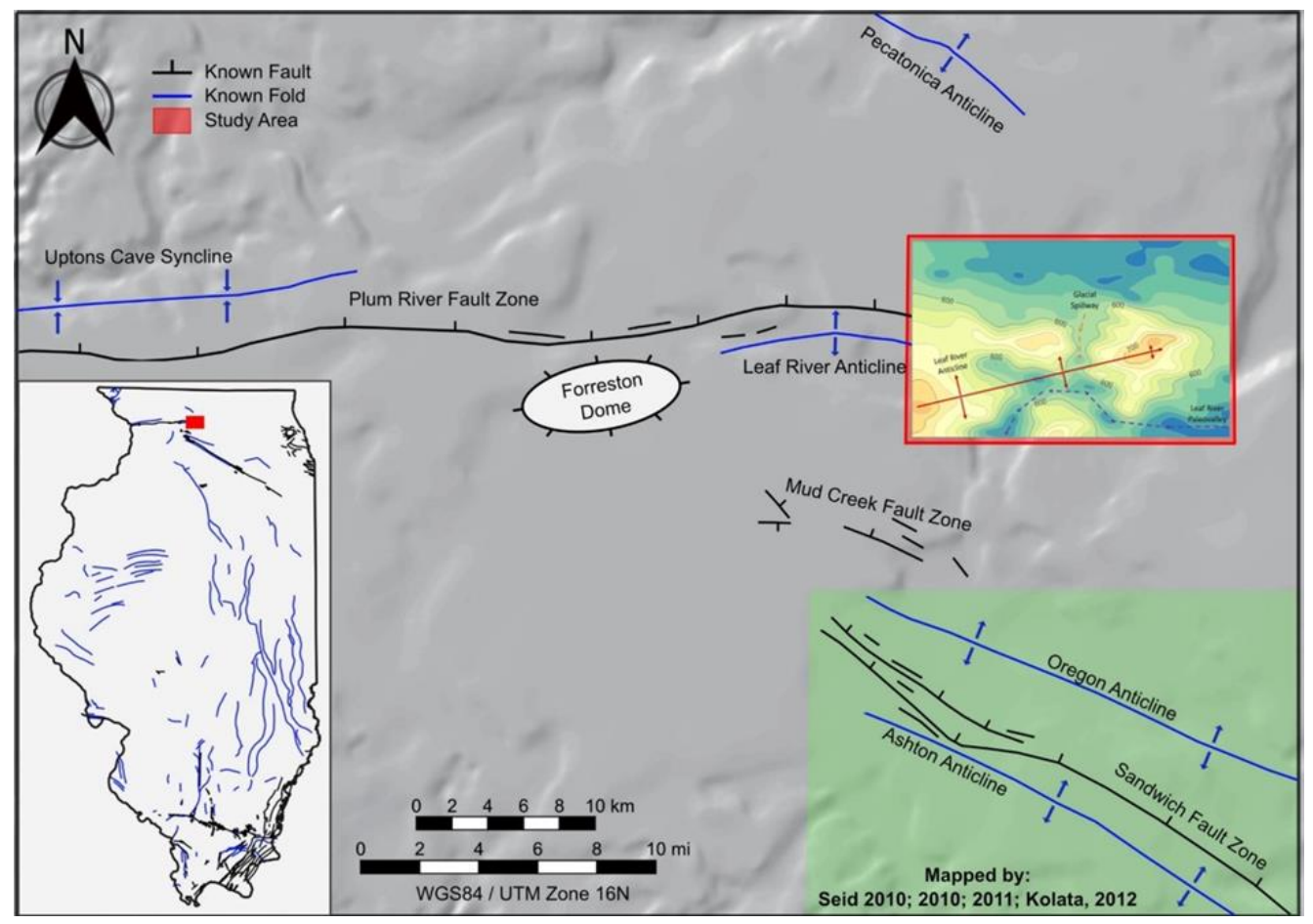

Figure 11: Contour map of the Leaf River anticline placed on top of the regional structure and bedrock topography modified from Horberg, 1950. 


\section{Bedrock Surface Contour Map}

The elevation model for the bedrock surface represents the paleo topography obscured by glacial drift in the study area. This colored contour map revealed the paleo-drainage network etched into bedrock geology in the study area. The Leaf River paleovalley follows a ten mile (16 kilometer) course at elevations between 500-600 feet (152-183) (figure 12). This feature begins as a deep and wide valley in the east that tightens to a half mile ( 0.8 kilometer) wide gorge in the west. The walls of the paleovalley are made up of Galena and Platteville carbonates, while the floors consist of the St. Peter sandstone (figure 1; Anderson, 2005). Synthetic sand wells were used to map the deepest section of the paleovalley in the east (figure 8). Considering this, the exact width and depth of the paleovalley is uncertain along the southeastern edge of the domain. Overall, the course and geometry of the Leaf River paleovalley match the regional interpretations (figures 12, 13)

The glacial spillway follows a southwest six mile (10 kilometers) course at elevations between 620-700 feet (189-213 meters). The width of the spillway is a constant half mile until it connects with a tributary of the Leaf River paleovalley at the center of the map (figure 12). The spillway cuts into Galena and Platteville carbonates for most its course, only eroding into the St.

Peter sandstone at the interface with the Leaf River paleovalley (Figure 1; Anderson, 2005). The positions and orientations of the Leaf River Paleovalley and spillway mapped in this study matched with those reported in earlier investigations (Figures, 12, 13; Horberg 1950; Horberg and Anderson, 1956; Anderson, 2005). 


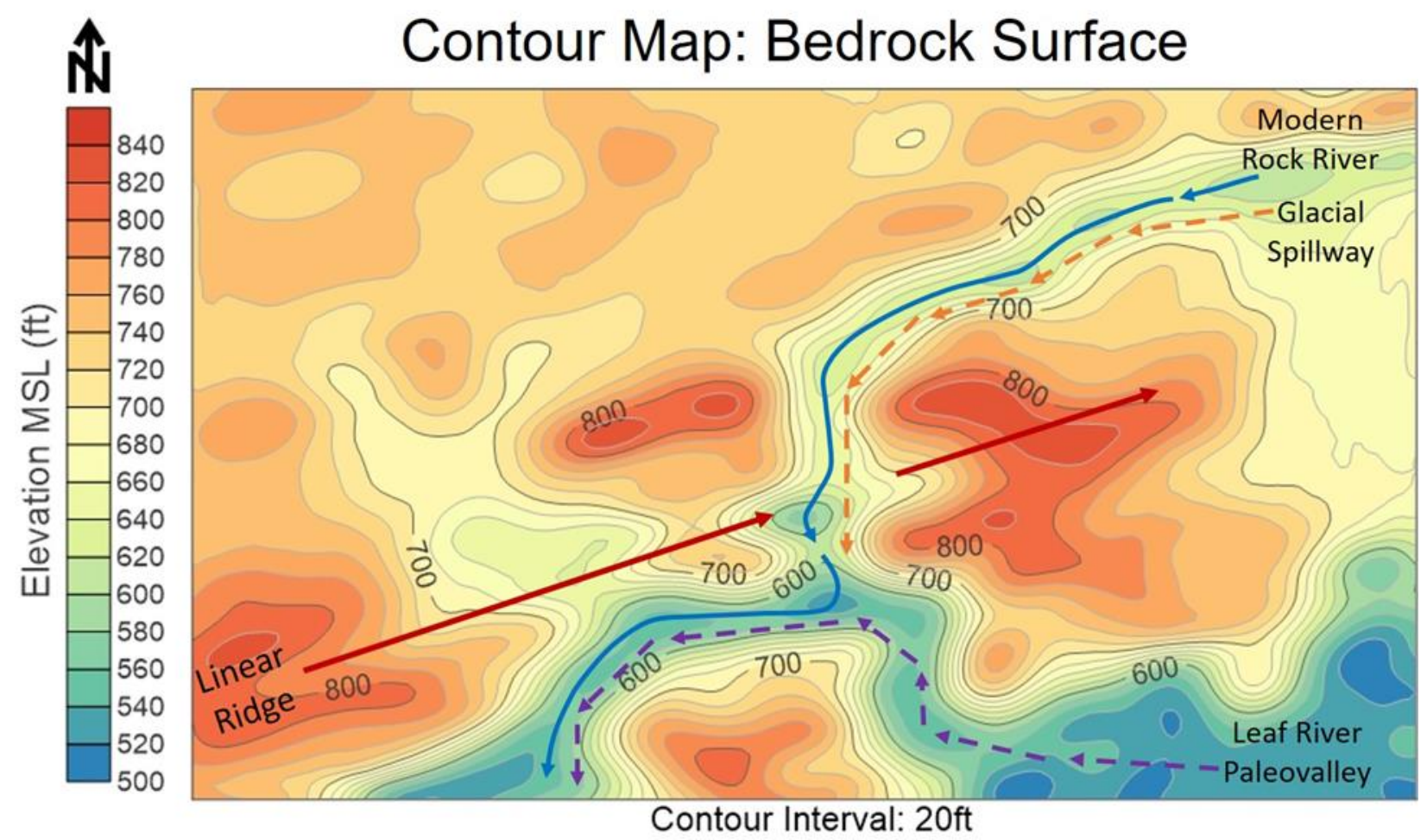

Figure 12. The elevation contour map for the buried bedrock paleo topography.

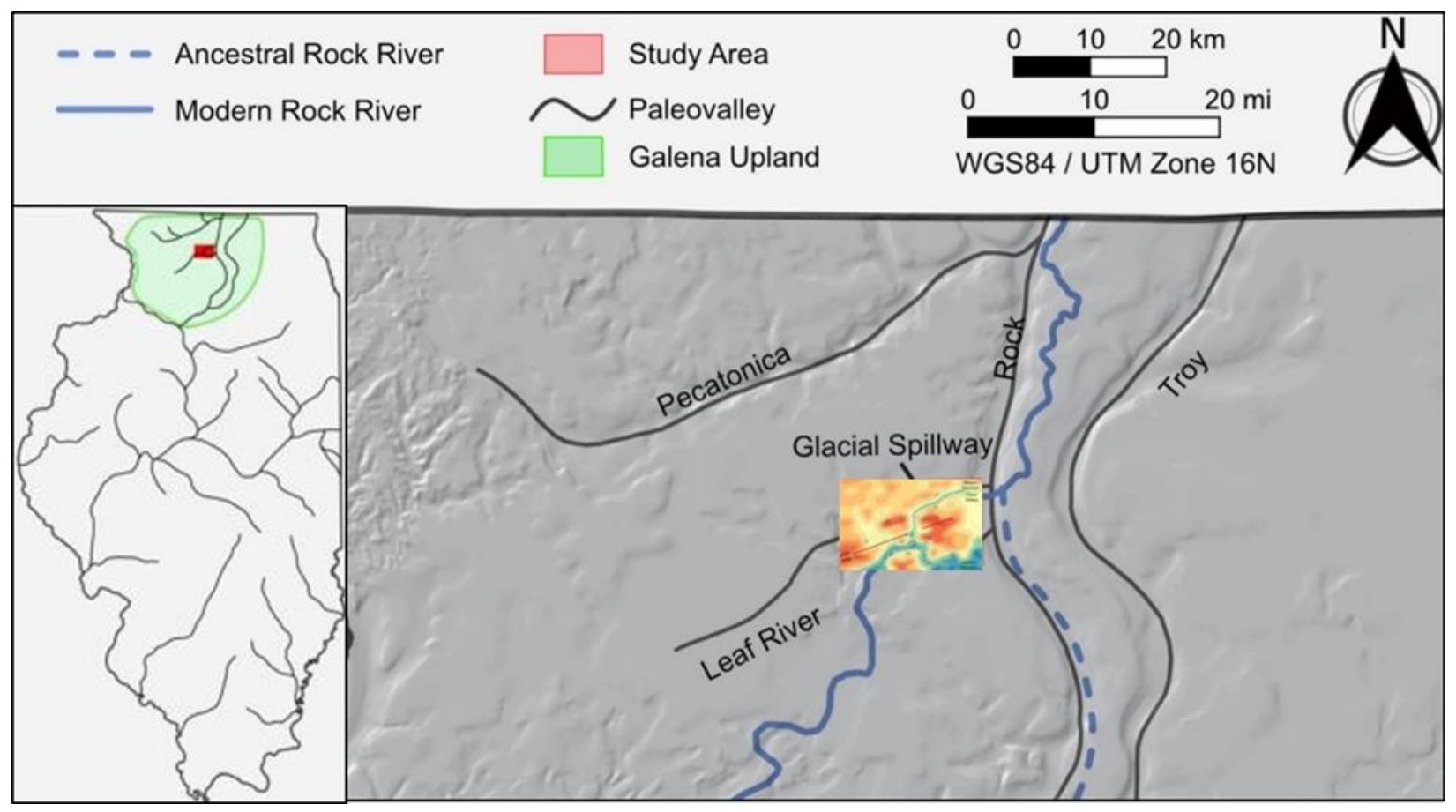

Figure 13. Bedrock contour map placed on top of the regional paleo topography modified from Horberg, 1950. 


\section{CHAPTER IV: DISCUSSION}

\section{Leaf River Anticline}

The structure present in the contour map of the St. Peter top is interpreted to be an extension of the Leaf River anticline (figures 10, 11; Kolata and Buschbach, 1976; Kolata and Bushbach, 1978, Ludvigson and Bunker, 1989). This footwall fold projects eastward from the rim of the Forreston dome into the study area (figure 11). This anticline created the east-west high relief topography expressed on the bedrock surface (figure 12). The orientation of the Leaf River anticline influenced the subsequent entrenchment and positioning of the Leaf River paleovalley and the glacial spillway (figures 12, 13; Horberg 1950; McGinnis 1968; Anderson 2005).

Prior work has the Leaf River anticline nosing out to closure at the western margin of the study area (figure 2; Kolata and Buschbach, 1976; Kolata and Bushbach, 1978, Ludvigson and Bunker, 1989). These interpretations are based on structure contours using the Glenwood formation as a marker horizon (figure 3). The silty sandstone that makes up the Glenwood is a discontinuous unit that was not observed in the study area. Using the St. Peter sandstone as a marker horizon clearly indicates that the anticline extends eastward into the domain and tightens to closure along the eastern boundary (figures 10, 11).

\section{Plum River Fault Zone}

Prior works have attributed the development of the PRFZ to an undocumented shear zone in the Precambrian basement (Kolata and Buschbach, 1976; Kolata and Bushbach, 1978, Ludvigson and Bunker, 1989). Examination of the Precambrian basement terranes present in the Midwest indicate that the approximate boundary of the Yavapai-Mazatzal crustal suture intersects the PRFZ at an oblique angle (figure 14; Craddock et al., 2017). The reactivation of 
suture zone along the Yavapai-Mazatzal boundary provided the necessary structural offset and uplift to incite development of the Plum River Fault Zone.

Examination of the Franconia and St. Peter structure contours (figure 4, 10, 11) indicates that the PRFZ has propagated a footwall fold from the middle Cambrian through the Ordovician bedrock surface (Kolata and Buschbach, 1983; Nelson 1995). This structural activity, similar in style to a Riedel shear, originated at a basement penetrating suture zone created by the accretion of the Yavapai and Mazatzal terranes in the middle Proterozoic (figure 14; Craddock et al., 2017). 


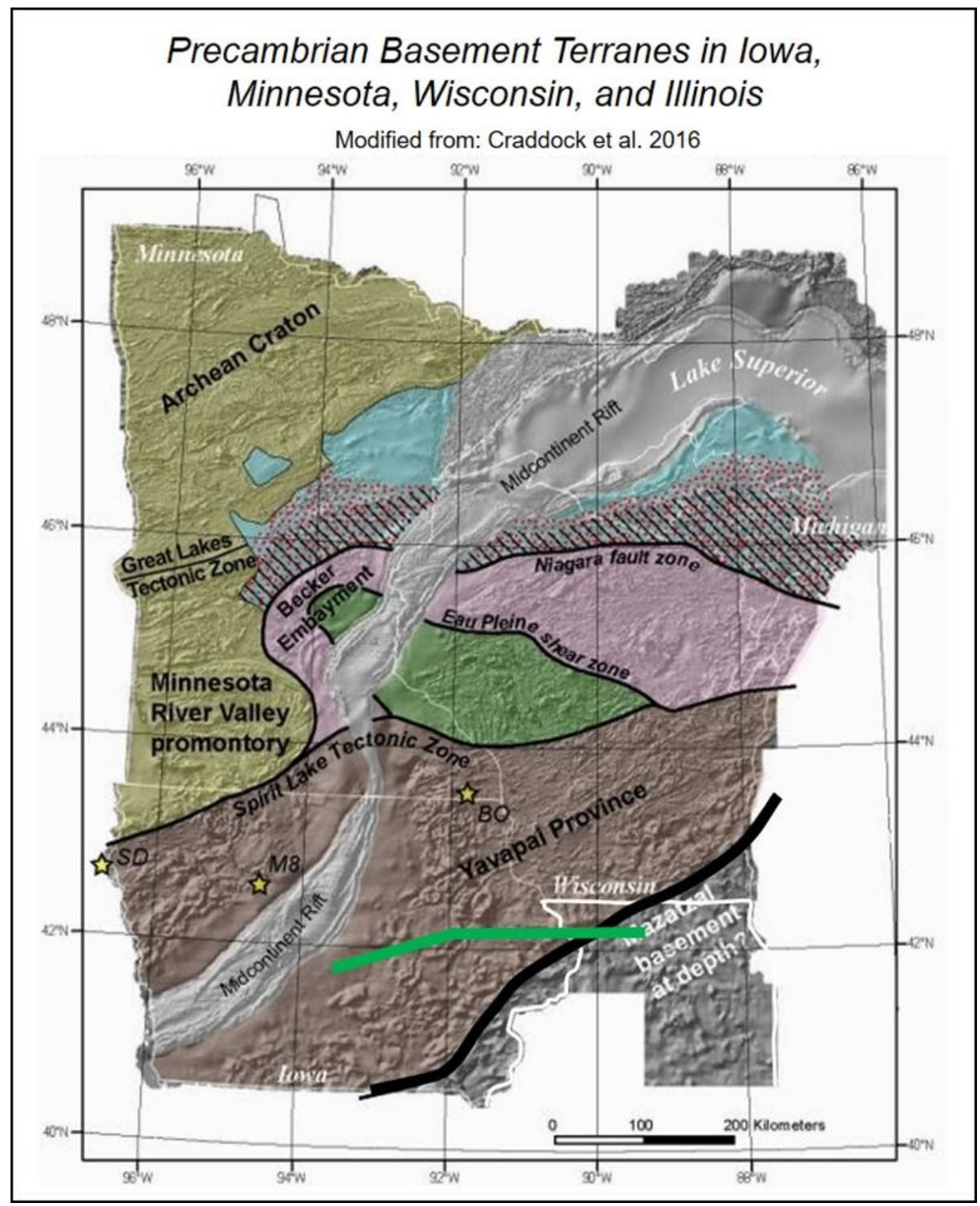

Figure 14. Precambrian basement terranes in the north-central United States. Note that the approximate Yavapai-Mazatzal suture zone, marked in black, runs through northern Illinois. The PRFZ, marked in green, intersects the suture at an oblique angle. Modified from Craddock et al., 2017. 


\section{Rock River Diversion}

Prior to the Pleistocene, the ancestral Rock River followed the course of the Rock paleovalley before connecting with a tributary of the ancient Mississippi river (figure 5). However, the ice damns that overloaded the Rock bedrock valley also forced the permanent diversion of the ancestral Rock River during the Illinois Glacial Episode (figure 5). As it flows westward, the modern Rock River follows the course of the glacial spillway and the Leaf River paleovalley (figures 12, 13; Horberg 1950; Horberg and Anderson, 1956; Willman and Frye 1970; Anderson 2005).

The entrenchment of the glacial spillway created a direct drainage route between the Rock and Leaf River paleovalleys that did not exist prior to the Illinois glacial episode. Once the spillway connected with the Leaf River paleovalley (figures 12,13), the drainage network in the study area was now capable of handling permanent westward flow of surface water. During the Wisconsin episode, the terminal ice front dammed and obstructed flow in the Rock River bedrock valley. The landscape compensated by rerouting the Rock River through the modified drainage network in the study area. By the end of the Wisconsin episode, the Rock River was permanently following its modern course (figures 12, 13; Horberg 1950; Horberg and Anderson, 1956; Willman and Frye 1970; Anderson 2005). 


\section{CHAPTER V: CONCLUSION}

The ancient bedrock landscape in Northern Illinois has been obscured by glacial-fluvial activity throughout the Pleistocene. Buried beneath mantle of glacial drift, a complex geomorphic and structural history is superimposed onto the ancient topography. The drainage history and deformation in the region has been studied extensively, but separately, throughout the $20^{\text {th }}$ century. The purpose of this study is to deconstruct the relationship between the Leaf River anticline and the paleo topography located at the terminus of the Plum River Fault Zone in Northern Illinois. Public water well data and Ordinary Kriging were used to construct elevation models of the bedrock paleo topography and the Leaf River anticline.

The contour maps derived from the elevation models provided detail depictions of the ancient bedrock landscape and subsurface structure in the study area. The Leaf River anticline is interpreted to be a component of a positive flower structure along the footwall terminus of the Plum River Fault zone. The linear topographic high observed in this study and by prior works was generated by the deformation of the Leaf River anticline (Horberg, 1950; Horberg and Anderson, 1956; Frye 1963; Anderson 1988; 2005). The topographic high controlled local drainage and led to the development of the Leaf River paleovalley prior to the Pleistocene. The catastrophic failure of an ice damn during the Illinois Glacial Episode carved a glacial spillway into the north flank of the anticline that interfaced with a tributary of the Leaf River paleovalley. This rerouted the preglacial drainage network and permanently diverted the ancient Rock River to its modern day position.

Ultimately, the subsurface geometry of the Leaf River anticline and its relationship to the local bedrock paleo topography was revealed by the elevation models. The positions and development of the Leaf River paleovalley and glacial spillway interpreted in this study aligned 
with the regional interpretations for the evolution of the ancient bedrock landscape established in prior works (Horberg, 1950; Horberg and Anderson, 1956; Anderson, 1988; 2005). However, this study revealed that the Leaf River anticline, and by association, the terminus of the Plum River Fault Zone extends farther east into the region than indicated by prior works (Willman, Templeton, 1951; Kolata and Buschbach, 1976; 1978; Ludvigson and Bunker, 1989). This is a unique interpretation that is only supported by the evidence presented in this study. The new position of Leaf River anticline and the magnitude of deformation at the terminus of the Plum River Fault Zone needs to be confirmed by additional geophysics and field studies. 


\section{REFERENCES}

Abrams, D.B., Hadley, D.R, Mannix, D.H., Roadcap, G.S., Meyer, S.C., Hlinka, K.J., Rennels, K.L., Bradbury, K.R., Chase, P.M., and Krause, J.J., 2015, Changing Groundwater Levels in the Sandstone Aquifers of Northern Illinois and Southern Wisconsin: Impacts on Available Water Supply: Illinois State Water Survey, Contract-Report 2015-02, 121 p.

Anderson, R.C., 1988, Reconstruction of preglacial drainage and diversion by earliest glacial forebulge in the upper Mississippi Valley region, Geology, v. 16, p. 254.

Anderson, R.C., 2005, Geomorphic History of the Rock River, South-Central Wisconsin, Northwestern Illinois: Illinois State Geological Society, Circular 565, 40 p.

Barnhardt, M.L., and Berg, R.C., 2000, Methods and standards for the 3D geologic mapping of the Antioch Quadrangle, Lake County, Illinois: A pilot study: Illinois State Geological Survey Open File Series 2005-12, p. 1-43.

Brown, P.A., and Kennett, J.P., 1998, Megaflood erosion and meltwater plumbing changes during last North American deglaciation recorded in Gulf of Mexico sediments: Geology, v. 26, p. 599-602.

Chung, J. and Rogers, D., 2012, Estimating the position and variability of buried bedrock surfaces in the St. Louis metro area: Engineering Geology, v. 126, p. 37-45.

Craddock, J.P., Malone, D.H., Porter. R., Compton, J., Lucjaz, J., Day, J.E, and Johnston, S.T., 2016, Paleozoic Reactivation in the Applachian-Ouchita-Marathon Foreland: Far-Field Deformation across Pangea: IN PRESS.

Curry, B.B. and Yansa, C.H., 2004, Evidence for stagnation of the Harvard sublobe (Lake Michigan lobe) in northeastern Illinois, USA, from 24,000 to 17,600 BP and subsequent tundra-like ice-marginal paleoenvironments from 17,600 to 15,700 BP: In Géographie Physique et Quaternaire; Université de Montréal: Montreal, QC, Canada, v. 58, p. 305321.

Cutler, P.M., Colgan, P.M. and Mickelson, D.M., 2002, Sedimentologic Evidence for Outburst Floods from the Laurentide Ice Sheet Margin in Wisconsin, USA: Implications for Tunnel-Channel Formation: Quaternary International, v. 90, p. 23-40.

Davis, J.C., 2002, Statistics and Data Analysis in Geology: New York, John Wiley and Sons, 638 p.Frye, J.C., 1963, Problems of interpreting the bedrock surface of Illinois: Illinois Academy of Science Transactions, v. 56, p. 3-11.

Herzfeld, U.C., Mats, E.G., Holmlund, P., 1993, On the influence of kriging parameters on the cartographic output: a study in mapping subglacial topography: Mathematical Geology, v. 25.7, p. 881-900.

Horberg, L., 1950, Bedrock Topography of Illinois: Illinois State Geological Survey, Bulletin 73, $115 \mathrm{p}$. 
Horberg L., and Anderson R.C., 1956, Bedrock Topography and Pleistocene Glacial Lobes in Central United States: Journal of Geology, v. 64, no. 2, p. 101-116.

Kehew, A.E., and L. Clayton, 1986, Origin and large-scale erosional features of glacial-lake spillways in the northern Great Plains: Geological Society of America Bulletin, v. 97, p. $162-177$.

Kempton, J.P., et al., 1991, Mahomet Bedrock Valley in east-central Illinois; topography, glacial drift stratigraphy, and hydrogeology: Geological Society of America Special Papers v. 258, p. 91-124.

Kolata, D.R., and Buschbach, T.C., 1976, Plum River Fault Zone: Illinois State Geological Survey, Circular 491, 24 p.

Kolata, D.R., and Buschbach, T.C., 1978, The Sandwich Fault Zone of Northern Illinois: Illinois State Geological Survey, Circular 505, 26 p.

Kolata, D.R., and Graese, A.M., 1983, Lithostratigraphy and Depositional Environments of the Maquoketa Group (Ordovician) in Northern Illinois: Illinois State Geological Survey, Circular 528, 49 p.

Kolata, D.R., 2012, Bedrock Geology of Grand Detour Quadrangle, Ogle and Lee Counties, Illinois: Illinois State Geological Survey, Illinois Geologic Quadrangle Map, IGQ Grand Detour-BG, 2 sheets, 1:24,000.

Kron, N., Malone, D.H. and Peterson, E.W., 2016, Three-Dimensional Geologic Model of the Pecatonica Gas Storage Field, Winnebago County, Illinois: World Journal of Environmental Engineering, v. 3, p. 121-125.

Lau, J., Thomason, J.F., Malone, D.H., Peterson, E.W., 2016, Modeling the sediment fill of the pre-glacial Troy Bedrock Valley, McHenry County, IL, USA: J. Geosci. Environ. Protect., v. 4, p. 100-115.

Leighton, M.M. and J.A. Brophy, 1961, Illinoisian Glaciation in Illinois: The Journal of Geology, v. 69, p. 1-39.

Leighton, M.M., G. Ekblaw, and L. Horberg, 1948, Physiographic Divisions of Illinois: Journal of Geology, v. 56, p. 16-33.

Leverett, F., 1895, Preglacial valleys of the Mississippi and its tributaries: Journal of Geology, v. 3, p. 740-763.

Leverett, F., 1921, Outline of the Pleistocene history of the Mississippi Valley: Journal of Geology, v. 29, p. 615-626.

Ludvigson, G.A. and Bunker, B.J., 1989, New Perspectives on the Paleozoic history of the Upper Mississippi Valley: An examination of the Plum River Fault Zone: Iowa Geological Survey, Guidebook No. 8, 259 p. 
Marshak, S., Nelson, W.J., and McBride, J. H., 2003, Phanerozoic strike-slip faulting in the continental interior platform of the United States: examples from the Laramide Orogen, Midcontinent, and Ancestral Rocky Mountains: Geological Society, London, Special Publications, v. 210, p. 159-184.

McGinnis, L.D., Lempton, J.P., and Heigold, P.C., 1963, Relationship of Gravity Anomalies to a Drift-Filled Bedrock Valley System in Northern Illinois: Illinois State Geological Survey, Circular 354, $27 \mathrm{p}$.

McGinnis, L.D., 1968, Glacial Crustal Bending, Geological Society of America Bulletin, v. 79, p. 769.

McGinnis, L.D., and Heigold, P.C., 1976, The Gravity Field and Tectonics of Illinois: Illinois State Geological Survey, Circular 494, 29 p.

Nelson, J.W., 1995, Structural Features in Illinois: Illinois State Geological Survey, Bulletin 100, $150 \mathrm{p}$.

Olea, R.A., 1999, Geostatistics for Engineers and Earth Scientists: Boston, Kluwer Academic Publishers, $303 \mathrm{p}$.

Seid, M.J., 2010, Bedrock Geology of Daysville Quadrangle, Ogle County, Illinois: Illinois State Geological Survey, USGS-STATEMAP contract report 2 sheets, 1:24,000 scale.

Seid, M.J., 2010, Bedrock Geology of Oregon Quadrangle, Ogle County, Illinois: Illinois State Geological Survey, USGS-STATEMAP contract report 2 sheets, 1:24,000 scale.

Seid, M.J., 2011, Bedrock Geology of Mount Morris Quadrangle, Ogle County, Illinois: Illinois State Geological Survey, USGS-STATEMAP contract report, 2 sheets, 1:24,000.

Van Hoesen, 2014, A Geographic Information Systems based approach to derivative map production and visualizing bedrock topography within the town of Rutland, Vermont, USA: Geo-Information, v. 3, p. 130-142.

Visocky, A.P., Sherril, M.G., and Cartwright K., 1985, Geology, Hydrology, and Water Quality of the Cambrian and Ordovician Systems in Northern Illinois: Illinois State Water Survey, Cooperative Groundwater Report 10, 144 p.

Willman, H.B., and Templeton, J.S., 1951, Cambrian and lower Ordovician exposures in Northern Illinois: Transactions of the Illinois State Academy of Science, v. 44, p. 109125.

Willman, H.B., and Frye, J.C., 1970, Pleistocene stratigraphy of Illinois: Illinois State Geological Survey, Bulletin 94, 219 p.

Willman, H.B., 1973, Rock stratigraphy of the Silurian System in northeastern and northwestern Illinois, Illinois State Geological Survey, Circular 479, 55 p. 
Willman, H.B., and Kolata, D.R. 1978, The Platteville and Galena Groups in Northern Illinois: Illinois State Geological Survey, Circular 502, 84 p.

Workman, L.E., 1937, The preglacial Rock River valley as a source of groundwater for Rockford: Illinois Academy of Science Transactions, v. 30, p. 245-247.

Zimmerman, D., Pavlik, C., Ruggles, A., and Armstrong, M.P., 1999, An experimental comparison of ordinary and universal kriging and inverse distance weighting: Mathematical Geology, v. 31, p. 375-389. 